\title{
CEO COMPENSATION, FAMILY CONTROL, AND INSTITUTIONAL INVESTORS IN CONTINENTAL EUROPE
}

\author{
Ettore Croci $^{\mathrm{a}}$ \\ Università degli Studi di Milano - Bicocca \\ Halit Gonenc ${ }^{\mathrm{b}}$ \\ University of Groningen \\ Neslihan Ozkan ${ }^{\mathrm{c}}$ \\ University of Bristol
}

\begin{abstract}
This paper investigates the impact of family control and institutional investors on CEO pay packages in Continental Europe, using a large data set of 915 listed firms with 4,045 firm-year observations from 14 countries over the period 2001-2008. We find that family control curbs the level of CEO total compensation which includes both cash and equity-based compensation. This effect is particularly accentuated in firms with family CEOs, indicating that controlling families do not use CEO compensation to expropriate wealth from minority shareholders. We also find that the impact of institutional ownership on CEO compensation varies depending on whether institutional investors are foreign or domestic. Our results show that domestic institutional investors play an active role in determining the level of CEO compensation by increasing the pay-for-performance sensitivity, while foreign institutional ownership increase CEO total compensation without aligning pay with performance. We also provide evidence that institutional investors partially counterbalance the negative effect of family control on CEO compensation, especially in family firms with professional CEOs, and increase the level of CEO total compensation.
\end{abstract}

EFM Classification Codes: 190, 150

Keywords: CEO compensation; family firms; institutional investors; Europe.

${ }^{a}$ Università degli Studi di Milano-Bicocca, Facoltà di Economia, Via R. Bicocca degli Arcimboldi, 8 ed. U7, 20126 Milan, Italy, e-mail: ettore.croci@unimib.it

${ }^{\mathrm{b}}$ University of Groningen - Faculty of Economics and Business, P.O. Box 800 Groningen 9700 AV, Netherlands, email: h.gonenc@rug.nl

${ }^{\mathrm{c}}$ University of Bristol, The School of Economics, Finance and Management, 8 Woodland Road, Bristol,BS8 1TN, UK, e-mail: N.ozkan@bristol.ac.uk 


\section{Introduction}

CEO pay has recently sparked an intense debate in the media, among politicians and the public in Europe. ${ }^{1}$ For instance, Germans raised eyebrows when Wendelin Wiedeking, CEO of Porsche AG, became Europe's highest-paid businessman by earning an estimated $€ 67 \mathrm{~m}$ in $2008 .^{2}$ JeanClaude Juncker, president of the European Union's "Eurogroup" of finance ministers, called excessive executive pay "scandalous" and a "social scourge" and demanded an action against it. ${ }^{3}$ Institutional shareholders have also voiced their concerns about executive pay in European companies and stopped some from rewarding their CEOs with contentiously high compensation packages. ${ }^{4}$

Despite the widespread media and public attention on CEO compensation packages, there has been little empirical evidence about how the pay structure is designed in Continental Europe. In a recent paper, Fernandes et al. (2009) document that CEOs are paid more in the US than in other countries, including Europe, and they quantify this premium as about 40\%, after controlling for several firm, governance, industry and CEO specific characteristics. They find that this premium is explained by the different structure of compensation, with US firms relying more on incentive compensation than non-US firms. In this paper, we take a closer look at one of the governance mechanisms and examine how the ownership structure of the firm affects CEO compensation. In particular, this paper aims to investigate various aspects of CEO compensation

\footnotetext{
1 "Europe: A meeting of minds", Richard Milne, Financial Times, February 28, 2010; "Germany gets tough on executive pay", Bertrand Benoit, Financial Times, May 29, 2009; "Germany to target stock options in clampdown on executive pay", Bertrand Benoit, Financial Times, July 10, 2008; "Dutch pioneers blaze trail on executive pay", Richard Milne, Financial Times, August 31 2009; "France eyes curbs on executive pay", Ben Hall, Financial Times, May 29, 2008; "Minder's mission", The Economist, Jun 21 2007.

2 "Accent on égalité: Europe loses patience with its wealthy elite", John Thornhill, Richard Milne and Michael Steen, Financial Times, June 8, 2008.

3 "EU finance ministers declare war on excessive boardroom pay", Stephen Castle, New York Times, May 14, 2008.

4 "European investors balk at director pay", Kate Burgess and Richard Milne, Financial Times, June 1 2009. Some firms among those where institutional investors blocked the CEO compensation are: Heineken, Volvo, and Carrefour.
} 
in Continental Europe, examining the effect of family control and institutional investors on the CEO pay level and pay-for-performance sensitivity. To date, research on CEO compensation has focused mainly on US and UK firms, and the results from the few studies on Continental Europe have been mixed, as we discuss in Section $2 .{ }^{5}$ Considering the characteristics of corporate governance in Continental Europe, one would expect major differences between the UK or US and Continental Europe about how CEO compensation packages are determined. For instance, different from US and UK, concentrated ownership structure is prevalent in Continental Europe (La Porta et al., 1999). In particular, families own large, and often controlling, equity stakes in most of the listed firms across Continental Europe (Faccio and Lang, 2002, and Barca and Becht, 2001).

Agency theory suggests that family control might have a significant impact on CEO compensation structure. Agency costs that arise from separation of ownership and control would be low in family firms since families as major shareholders would have strong incentives to provide monitoring for the management (Shleifer and Vishny, 1997). Thus, equity-based compensation, which can play a significant role in aligning the interests of CEOs and shareholders in widely-held firms, would not be expected to be an important part of CEO compensation in family firms.

\footnotetext{
${ }^{5}$ See Conyon et al. (2010). One major reason for the limited number of studies has been the scarce availability of data on executive compensation; in fact, until recently most Continental European countries did not require extensive disclosure for top executive pay packages. There have been some recent developments in the disclosure rules across Europe. In 2004, the EU Commission adopted a recommendation on executive compensation. The main aim was to ensure that listed companies disclose information about their executive compensation packages including the level of pay and structure of pay with stock options and awards. Thus, in the recent years shareholders in European companies have better information about companies' remuneration policy. As part of the recommendations, it was emphasized that executive compensation should be included in the agenda of the shareholders' general meeting. Additionally, it was recommended that executive pay packages should be submitted to a vote, which may be either binding or advisory. In Denmark, in 2007 a new law, which requires firms to present full information about their remuneration policy and be approved by a majority of shareholders, was passed.
} 
However, agency costs might arise from conflicts of interests between family and minority shareholders in firms with concentrated family ownership. Families with major share ownership can expropriate wealth from minority shareholders in many ways (Morck and Yeung, 2003; Bertrand and Schoar, 2006). For instance, CEOs, in particular family CEOs, may receive excessive compensation packages in family firms, which could be viewed as part of their extraction of the private benefits of control. On the contrary, Gomez-Mejia et al. (2003) note that risk-averse CEOs might be willing to accept a lower compensation in exchange for higher job security in family firms, especially if they are related to owners. Family ties can also increase the commitment to the firm: a family CEO would be less likely to leave the firm for another company. Thus, CEO compensation in family firms might be lower than that in non-family firms. This paper aims to provide empirical evidence on how family control can influence CEO compensation in Continental European firms and whether the level of CEO compensation reflect rent seeking by controlling family shareholders.

While family control is common in Continental Europe, share ownership of institutional investors, and in particular, those of foreign institutional investors, has recently grown considerably (Ferreira and Matos, 2008). Thus, institutional investors could be major shareholders side by side with controlling family shareholders. In this paper, we investigate whether the institutional investors can affect CEO compensation packages in Continental Europe. Previous studies report that institutional investors can play an important role in reducing excessive levels of CEO compensation and have a positive impact on CEO pay-for-performance link in US and UK firms. ${ }^{6}$ However, there has been no evidence on how institutional investors influence CEO compensation in firms with controlling family shareholders. This paper aims to

\footnotetext{
${ }^{6}$ See, Hartzell and Starks (2003) for US companies and Ozkan (2010) for UK companies.
} 
fill this gap by examining how institutional investors interact with family shareholders in determining CEO compensation. Additionally, we focus on the impact of hedge fund ownership on CEO compensation. While recent research has investigated hedge fund activism (Brav et al., 2008; Klein and Zur, 2009), their effect on CEO compensation is still unknown, especially in an environment like Continental Europe, where recently hedge fund ownership has increased considerably.

For our empirical analysis, we create a large panel data of Continental European firms over the period 2001-2008. Our data set consists of 4,045 firm-year observations and 915 firms. Different from the previous studies focusing on executive compensation in individual European countries, we examine CEO compensation practices in 14 Continental European countries. ${ }^{7}$ In our empirical analysis, we consider both cash and equity-based components of CEO compensation. Furthermore, we control for a comprehensive set of corporate governance variables including $\mathrm{CEO}$ and board characteristics.

We find that firms with family control offer their CEOs lower compensation than those firms without family control (non-family firms). Further, family CEOs are paid less than professional CEOs in family firms. Thus, controlling family shareholders do not seem to expropriate wealth from minority shareholders through excessive CEO compensation. Our results also show that institutional ownership has a positive impact on the level of CEO cash and total compensation. At first sight, this finding may suggest that institutional ownership does not provide monitoring for determining the level of CEO compensation in Continental Europe, which is contrary to the findings from UK and US-based studies reporting that institutional

\footnotetext{
7 The countries are: Austria, Belgium, Denmark, Finland, France, Germany, Greece, Italy, Netherlands, Norway, Portugal, Spain, Sweden, and Switzerland.
} 
investors put a check on CEO compensation. ${ }^{8}$ However, when we classify institutional ownership into foreign and domestic institutional ownership, we find that while foreign institutional investors have a positive and significant impact on CEO compensation, domestic institutional investors behave differently in family and non-family firms. In fact, while domestic institutional investors reduce CEO pay in non-family firms, they have a positive effect on CEO compensation in family firms. Thus, the impact of institutional investors on CEO compensation varies depending on the institutional investor's nationality. Additionally, we find that hedge fund ownership does not have a significant impact on the level of CEO total compensation. Finally, we find that both institutional investors and hedge funds increase the pay-for-performance sensitivity, especially when we examine the equity-linked compensation.

This paper offers contributions to the two strands of the literature. Firstly, our results complement empirical findings of Fernandes et al. (2009) and Conyon et al. (2010), who use cross-country data for their analysis of executive compensation. Similar to their studies, we use cross-country data for our analysis of the determinants of CEO compensation. However, we focus on the effect of family control, foreign and domestic institutional investors, and hedge funds on CEO compensation in Continental Europe. We show that family control curbs CEO compensation, reducing both the cash and the equity components of the pay. Family CEOs receive a lower pay, indicating that controlling families do not generally use CEO compensation to expropriate minority investors.

Secondly, this paper adds to the literature on institutional investors. Prior studies document that institutional investors, in particular, foreign institutional investors have been actively involved monitoring for various aspects of corporate decision making including CEO

\footnotetext{
${ }^{8}$ See, for example, Ozkan (2010) and Hartzell and Starks (2003).
} 
turnover, M\&As, and capital expenditures (Ferreira and Matos, 2008, Ferreira et al., 2009; Aggarwal et al., 2009). We offer evidence that institutional investors partially counterbalance the negative effect on CEO compensation exerted by family-control, especially in firms with professional CEOs. Since this increase is associated with a higher pay-for-performance sensitivity, this institutional investor effect is directed toward disenfranchising the professional manager from the controlling family. However, this effect is driven by domestic, not foreign institutional investors. This result is particularly important in light of recent evidence (Ferreira and Matos, 2008, Ferreira et al., 2009; Aggarwal, 2009) that there has been an increase of foreign institutional ownership around the world. Our results suggest that expectations that this surge in foreign institutional ownership may lead to a larger monitoring activity by these institutions may be exaggerated. Finally, in contrast to the anecdotal evidence on hedge fund activism, our findings reveal that hedge funds do not have a significant effect on CEO compensation.

The remainder of the paper is structured as follows. Section 2 discusses the literature and formulates the hypotheses. Section 3 presents a description of the sample and summary statistics. Section 4 provides a discussion of empirical tests and results about the effect of family control, institutional investors and their interaction with family control on CEO compensation. Section 5 concludes.

\section{Literature review}

\subsection{The effect of family control on CEO compensation}

Concentrated family ownership is the most prevalent type of ownership structure in Continental Europe (La Porta et al., 1999, Faccio and Lang, 2002, and Barca and Becht, 2001, Franks et al., 2009). Previous researchers including Morck and Yeung (2003) and Bertrand and Schoar (2006), 
argue that decisions in family firms can be made in the interests of the controlling family, whose interests may diverge from the interests of minority shareholders. Families, as large shareholders, value control and are often involved in company management, even if this may lead to poor firm performance (Perez-Gonzalez, 2006; Bennedsen et al., 2007). ${ }^{9}$

Family control is likely to affect both the level and composition of the CEO compensation packages. Given the high value families place on control, family firms may be reluctant to grant their executives stock awards and stock options, reducing the fraction of equity-based compensation executives receive. Moreover, the controlling family is often in a suitable position to monitor and, if necessary, fire the CEO if she does not perform according to the family's expectations. Thus, equity-based compensation might be relatively less important in family firms than in widely held firms, which would be more concerned about the alignment of the incentives of CEOs and those of shareholders. Additionally, if a family member is the CEO, firms do not need to align her interests with those of the shareholders through offering her equity-based compensation. Thus, we would expect a CEO who is a family member to receive relatively less equity-based compensation. McConaughy (2000) and Block (2008) report evidence consistent with this hypothesis for the US and Germany, respectively.

Families can also influence the level of CEO compensation. CEOs in family firms may receive larger compensation packages if they maximize the family's wealth allowing for extraction of private benefits of control by the controlling family. Consistent with this argument, Barontini and Bozzi (2009) show that in Italy family firms pay their CEOs more than other firms,

\footnotetext{
${ }^{9}$ Overall, on the effect of family ownership on firm performance, results are mixed. Part of the literature shows that the overall effect of family control on firm performance is positive (Anderson and Reeb, 2003; Villalonga and Amit, 2006; Andres, 2008; Villalonga and Amit, 2009). However, Claessens et al. (2002), Cronqvist and Nilsson, (2003), Maury (2006), Perez-Gonzales (2006) and Bennedsen et al. (2007), find that family ownership, negatively affects firm performance. Miller et al. (2007) find that the superior performance of family firms is limited to the cases where a lone founder runs the firm. Finally, a recent paper by Franks et al. (2009) finds that family firms outperform nonfamily firms in Continental Europe, but not in the UK.
} 
and that family CEOs are paid more than professional CEOs. They interpret this result as an evidence of rent extraction, arguing families over-compensate their CEOs to buy their loyalty and allow them to expropriate minority shareholders. Similar to Barontini and Bozzi (2009), Barak et al. (2008) provide evidence that excess compensation is a private benefit of control in Israel. ${ }^{10}$ However, they find that, while family CEOs are rewarded for bad performance, professional CEOs are rewarded when they increase firm value. In addition, Haid and Yurtoglu (2006) find a positive effect of family control on CEO compensation for a sample of German companies.

Alternatively, family control could have a negative impact on the level of CEO compensation. Risk-averse executives could be willing to accept lower compensation in exchange for higher job security in family-controlled firms, especially if they are related to owners (Gomez-Mejia et al., 2003). Family ties also increase the commitment of the executive to the firm, who will be less likely to leave the firm for another company and more prone to accept an even lower pay. Palmberg (2009) and Elston and Goldberg (2003) find a negative relationship between family control and executive compensation, for Sweden, and Germany, respectively.

Overall, the evidence of how family control can influence the CEO compensation packages is rather limited and inconclusive. This is perhaps not surprising given the different time periods and compensation data types used in the literature. For instance, Haid and Yurtoglu (2006) and Elston and Goldberg (2003) use total compensation of members of supervisory and managing board as a measure of compensation because of the lack of data at the individual director level. This paper aims to contribute to the literature providing cross-country analysis of

\footnotetext{
${ }^{10}$ Urzua (2009) shows that controlling families also use compensations of chairmen and board members to tunnel resources out of the firm.
} 
how family control can influence level of CEO compensation and pay-for-performance sensitivity using both cash and equity-based components of CEO compensation.

\subsection{The effect of institutional ownership on CEO compensation}

Institutional activism can benefit minority shareholders by reducing potential agency costs and ensuring that managers act in the best interests of shareholders. Institutional investors including mutual funds, pension funds, insurance companies, bank trusts, and university endowments, often own block shareholdings and alleviate the free-rider problem that occurs when ownership is dispersed. Thus, they can provide effective monitoring of the management and affect key strategic policies in corporations including decisions on CEO compensation packages (Gillan and Starks, 2000).

Institutional investors could have a moderating impact on CEO compensation packages as part of their monitoring activities. Therefore, one would expect institutional ownership and CEO compensation to be negatively related. Additionally, institutional investors could encourage firms to provide more performance-based compensation to their CEOs, establishing a significant and positive relationship between CEO pay and performance, as documented by Hartzell and Starks (2003) for the US firms. Despite the growing presence of institutional investors in Continental European capital markets, there has been little evidence on the role of institutional investors in determining CEO compensation packages in Continental Europe except some evidence of the negative impact of banks on executive compensation in Germany (Elston and Goldberg, 2003; and Haid and Yurtoglu, 2006). ${ }^{11}$

\footnotetext{
${ }^{11}$ However, there is some anecdotal evidence of institutional investor activism. See for example "European investors balk at director pay", Kate Burgess and Richard Milne, Financial Times, June 12009.
} 
In Continental Europe institutional investors can hold blocks of shares in familycontrolled firms, and therefore, they have to interact with the family owners. In these situations, they can provide monitoring for family owners and help protecting the interests of minority shareholders. Consequently, the presence of institutional investors can potentially reduce the agency costs in family firms (Tosi et al., 1999). Gomez-Mejia et al. (2003) argue that institutional shareholders should demand for a lower emphasis on long-term component of the CEO compensation package in family firms, especially if the CEO is a family member. In fact, the long-term component of CEO compensation, in the form of stock options or stock grant, would strengthen the ownership rights of the controlling family and family CEO and might contribute to more potential CEO entrenchment. Thus institutional investors can play an active role in determining CEO compensation structure in family firms.

In this paper, we examine how institutional investors interact with controlling family shareholders in determining CEO compensation packages in Continental Europe. Given that foreign institutional ownership has increased considerably in Continental Europe in recent years (Ferreira and Matos, 2008), it is important to understand how foreign institutional investors as well as domestic institutional investors influence corporate decisions on designing CEO compensation packages. Foreign institutional investors are less likely to have potential business relationship with firms, thus we expect them to be more effective monitors.

Recently, hedge fund activism has gained considerable attention both in financial press and academic circles (Brav et al., 2008, Klein and Zur, 2009, Becht et al., 2009, Becht et al., 2010). Hedge funds with major shareholdings would be expected to have an incentive to monitor the management and other controlling shareholders. Consistent with this view, some hedge funds state that one of their main objectives is to reduce excessive executive compensation and 
strengthen the link between executive pay and performance (Brav et al., 2008). One of the aims of this paper is to examine the relationship between hedge fund ownership and CEO compensation and test whether hedge funds play a role in establishing a positive and significant link between CEO pay and performance in Continental Europe over the period 2001 to 2008.

\subsection{Board and CEO characteristics}

In our empirical investigation we control for a set of governance variables which could have a significant impact on CEO compensation; board characteristics, such as board size, the proportion of independent non-executive directors, board busyness, and CEO characteristics including the CEO tenure and number of outside directorships held by the CEO.

Board of directors can play an important role in monitoring corporate decisions and protecting the interests of minority shareholders (John and Senbet, 1998). One of the most important duties of the board of directors is to monitor decisions on executive compensation packages (Monks and Minnow, 2008). Core et al. (1999) find that CEO compensation is higher when the proportion of independent directors is lower and board size is larger.

Other board characteristics including the number of outside directorships held by directors could also influence their monitoring ability and might have implications for CEO compensation packages. In fact, Ferris et al. (2003) and Fich and Shivdasani (2006) argue that serving on multiple boards overcommits an individual and, as a consequence, she shirks her responsibilities as a director. Additionally, several multiple outside directorships held by a CEO can be related to the quality and reputation of the CEO suggesting a positive impact on CEO compensation (Fama and Jensen, 1983). We also control for CEO tenure, which can be either a 
proxy for managerial entrenchment or experience with positive implications for firm performance.

\section{Sample, variables, and summary statistics}

We begin by extracting CEO compensation data for Continental European firms from BoardEx, a leading business networking service that provides in-depth information on executive compensation. ${ }^{12}$ Since the coverage of European firms in Boardex has improved considerably after 2000, we focus on the period from 2001 to 2008. Compensation data are available for 1067 Continental European firms during this period. ${ }^{13}$ We then obtain ownership data from the Thomson One Banker Ownership module, which provides detailed firm-level ownership information; and financial data are drawn from Datastream/Worldscope. We require companies with compensation data from Boardex to have available ownership data from Thomson One Banker and financial data from Datastream/Worldscope. Our final sample consists of an unbalanced panel of 915 firms with 4,045 firm/year observations. ${ }^{14}$

We define a firm as a family firm (FAMILY) if either its largest shareholder with ownership of at least $10 \%$ of firm's outstanding shares is a family or an individual, or the largest shareholder owning at least $10 \%$ of outstanding shares is controlled by a family. This definition of family firms is consistent with the one used by previous researchers, for example Faccio and Lang (2002). ${ }^{15}$ To identify CEOs we use BoardEx, which provides information on the role of the

\footnotetext{
${ }^{12}$ Ferreira et al. (2009) also use Boardex data for the non-US companies in their sample.

${ }^{13}$ The number of firms per year differs from year to year, since some firms are added because of new listings and expanded BoardEx coverage and some others are delisted during the sample period.

${ }^{14}$ The number of firms and observations for each sample countries are: Austria (4 and 19), Belgium (50 and 161), Denmark (8 and 30), Finland (13 and 51), France (253 and 1301), Germany (132 and 471), Greece (5 and 13), Italy (101 and 433), Netherlands (102 and 550), Norway (34 and 106), Portugal (5 and 13), Spain (34 and 140), Sweden (119 and 613), and Switzerland (54 and 143).

${ }^{15}$ Using a $20 \%$ threshold to define a family firm does not affect our results.
} 
directors as disclosed in company annual reports. We collect both annual CEO cash and equitybased compensation data from BoardEx. Cash compensation includes base salary and bonus. Equity-based compensation includes value of shares, share options and long-term incentive plans (LTIPs) granted in a given year. ${ }^{16}$ We present descriptive statistics for our full sample, and the subsamples of family and non-family firms in Panel A of Table 1 . All values are expressed in Euros. Our sample is fairly balanced between family and non-family firms. In fact, family firms represent $41.3 \%$ of our sample. The average (median) CEO total compensation in our sample is 1.56 million Euros (729,155 Euros). Consistent with Fernandes et al. (2009), who find that incentive compensation is highest in common law countries like the US and the UK, Continental European firms seem to rely more on cash compensation than equity-based compensation. In fact, more than half of our sample firms do not offer equity-based compensation. We observe that on average family firms offer a significantly lower total compensation than non family firms, 1.68 million vs. 1.39 million Euros (median: 813,286 Euros vs. 595,270 Euros). They also pay lower cash compensation and equity-based compensation than non-family firms do.

[Table 1 about here]

Panel B of Table 1 presents descriptive statistics for the ownership stakes by institutional investors, which include banks and trusts, insurance companies, investment advisors, pension funds, research firms, and sovereign wealth funds. TOTINST is the sum of the percentage of

\footnotetext{
${ }^{16}$ The descriptions of the components of equity linked composition are as follows: shares is the total value of shares that are awarded in the period. For the value of options, BoardEx provides two descriptions: 1) Intrinsic value of options awarded, which is part of the equity-linked compensation and calculated by multiplying the number of options awarded in the period by the difference of stock price, and 2) Estimated value of options awarded, which is a theoretical value to calculate the potential value of the option during the vesting period by using the Black Sholes model. We use the latter because most of the time intrinsic value is not available. For the value of LTIPs, BoardEx display the maximum value obtainable under the long term incentive plan.
} 
stakes held by institutional investors in a given company. We further classify institutional investors into domestic and foreign institutional investors. We follow Ferreira et al. (2009) and define foreign institutional ownership (FORINST) as the percentage of shares held by all institutions domiciled in a country different from the one in which the company is incorporated. Domestic institutional ownership (DOMINST) is defined as the percentage of shares held by all institutions domiciled in the same country in which the company is incorporated. HEDGEFUND is the percentage of the firm's equity held by hedge funds.

We note that average institutional ownership is $18.59 \%$, and it is relatively larger for nonfamily firms $(21.72 \%)$ than family firms $(14.10 \%)$. This difference could be partially explained by the fact that family firms already have a large shareholder, the family, and thus, fewer shares are available for institutional investors. We also observe that average foreign institutional ownership is $8.79 \%$, while average domestic institutional ownership is $10.15 \%$. Table 1 indicates that on average both domestic and foreign ownership are larger in non-family firms than in family firms. This observation is consistent with the findings from Leuz et al. (2009) and Doidge et al. (2007) that US institutions invest less in firms with large block ownership by insiders (e.g., managers and families) since they view them as potentially poorly governed. Further, Ferreira and Matos (2008) find that firm size is an important factor in institutional investment since institutional investors have concerns about liquidity and transaction costs. Thus, given that family firms are relatively smaller in size, they would be of less interest to institutional investors. $^{17}$

\footnotetext{
17 In unreported analysis, we also use another measures of institutional ownership concentration: institutional blockholder ownership, which is defined as the percentage of equity owned by institutional investors with at least $5 \%$ of the firm's outstanding shares. We find that institutional blockholders exist in $49.67 \%$ of firm-year observations. The average institutional blockholder ownership is $8.61 \%$. At least one foreign institutional blockholder is present in $24 \%$ of firm-year observations, while $35 \%$ of firm-year observations have at least one domestic institutional blockholder. We also use hedge fund blockholder ownership to measure the percentage of
} 
Panel C of Table 1 presents descriptive statistics for CEO and board characteristics. CEO is a family member in $39.5 \%$ of family firms. CEO TENURE is the number of years a CEO holds his position as CEO. We observe that on average CEOs in family firms have longer tenure than those in non-family firms: 6.38 years vs. 4.71 years. In particular, the average tenure for family CEOs is 8.73 years, well above the tenure of professional (non-family) CEO in family firms (4.84 years), which is remarkably similar to the CEO tenure in non-family firms. In general, CEO tenure could be a proxy for CEO quality measuring experience or be a proxy for managerial entrenchment.

We also use another proxy for the CEO's experience and prestige, CEOEXPR, which is measured by the total number of directorships that CEO holds in other quoted companies. Fama and Jensen (1983) argue that the number of outside directorships held by a CEO is related to the CEO's quality and reputation. If a CEO with a high number of outside directorship signals high CEO quality, then one would expect her to receive relatively larger compensation. We find that on average CEOs hold three directorships in other quoted companies, and there is no significant difference between family and non-family firms in terms of number of directorships held by CEOs.

BOARDSIZE is the total number of executive and non-executive directors. We note that family firms have smaller board size than non-family firms. The average board size in our sample (11.63) is similar to the one in the Eurozone subsample in Ferreira et al. (2009) which is 11.89. Following Fich and Shivdasani (2006), we use a variable measuring busyness of independent directors. We would expect busy boards to be less effective in their monitoring

equity owned by hedge funds with at least $5 \%$ of the firm's outstanding shares. Hedge fund blockholders exist only in $3 \%$ of firm-year observations, which can explain low average $(0.275 \%)$ for hedge fund blockholder ownership. Since the results obtained using these definitions are similar to those obtained with TOTINST, FORINST, and DOMINST, we omit these tables to save space. 
function. A board is defined as busy if it has $50 \%$ or more of non-executive directors holding three or more directorships. Overall, almost $95 \%$ of the boards are classified as busy in our sample firms. Fich and Shivdasani (2006) report that percentage of busy boards in their sample of US firms is 21.42. Thus, boards in our sample of Continental European firms seem relatively busier than boards of US firms. Finally, INDPDIR is the proportion of independent nonexecutive directors on the board. ${ }^{18} \mathrm{We}$ observe that on average one out of four directors is independent. Further, family firms seem to give fewer seats to independent directors in their boards. Independent directors are not affiliated with the company, so they would be expected to provide objective monitoring for the firm's management and protect the interests of minority shareholders.

Panel D of Table 1 reports descriptive statistics for firm-specific financial variables. All values are measured in Euro. MARCAP is the market capitalization of the firm. SALES and ASSETS are the firm's total sales and total assets, respectively. Following Ferreira et al. (2009), the natural logarithm of SALES is used as a proxy of size in the regression analysis. Return on Assets $(R O A)$ is the ratio of net income to total assets. Market to Book ratio $(M t o B)$ is the sum of market value of shareholders' equity and book value of total assets divided by total assets. Sales growth is the change in sales; and Return represents the annual stock return.

Additionally, following Linck et al. (2008) we use the standard deviation of stock returns (STDDEVRET) to control for the value of the CEO's firm specific information. CEOs in firms with high volatility would have more firm-specific information than outsiders and would require higher equity-based compensation to align their interests with those of shareholders. Since the

\footnotetext{
${ }^{18}$ Using Boardex, we identify independent directors among so-called "supervisory directors" (SD). For this description, we look for the term 'independent' or 'independent $N E D$ ' in the definitions of role for SD, where NED stands for non-executive director.
} 
cost of monitoring increases as the information asymmetry between managers and shareholders increases, and the cost of losing an informed CEO is higher than the cost of losing a CEO with no firm-specific information. Thus, we expect CEO compensation, particularly equity-based compensation, to be positively related to the standard deviation of stock returns. The comparison between family and non-family firms highlights a well-known result: family firms are smaller in size, measured by market capitalization, total sales, and total assets, than non-family firms. While family firms have better operating performance $(R O A)$ than non-family firms, we do not find any evidence of significant differences in stock return and standard deviation of stock returns between family and non-family firms.

In Table 2, we present the descriptive statistics for total, cash, and equity-based compensation, and institutional ownership across years from 2001 to 2008. Panel A of Table 2, reports the descriptive statistics for components of CEO compensation. We observe that during the sample period average cash compensation increased from 510,740 Euros to 770,610 Euros, while average equity-based compensation declined from 970,310 Euros to 381,490 Euros. Further, the median for total CEO compensation increased from 571,200 Euros in 2001 to 846,850 Euros in 2008, whereas the change in average CEO total compensation from 2001 to 2008 seems negligible. We observe that the peak of total and equity-based compensation occurred in 2006, which was the last full year before the financial crisis started in August 2007.

[Table 2 about here]

Panel B of Table 2 reports descriptive statistics for total and foreign institutional ownership across years for our sample of family and non-family firms. The average total institutional ownership varies between 16.6 percent and 21.4 percent for our full sample over the 
period 2001-2008. Similar to Aggarwal et al. (2009), we observe that the average foreign institutional ownership has grown considerably from 6.9 percent in 2001 to 12 percent in 2008 and accounted for more than half of the total institutional ownership. Finally, we observe that total institutional ownership and foreign institutional ownership are lower in family firms than non family firms over the sample period. We report the breakdown of CEO compensation and institutional ownership by country in the Appendix.

\section{4. Empirical tests and results}

\subsection{Regression model}

To investigate the relationship between family control, institutional investors and CEO compensation, we use the following regression model:

$$
\begin{aligned}
& \text { LN }\left(\text { COMPENSATION }_{i t}\right)=\alpha+\phi_{1} \text { FAMILY }_{i t}+\phi_{2} \text { INSTOWN }_{i t}+\phi_{3} \text { PERFORMANCE }_{i t} \\
& +\sum_{k=1}^{n} \gamma_{k} \text { GOVERNANCE }_{k, i t}+\sum_{l=1}^{m} \delta_{l} \text { CONTROLVARIABLES }_{l, i t}+\varepsilon_{i t}
\end{aligned}
$$

where the dependent variable, $L N\left(\right.$ COMPENSATION $\left._{i t}\right)$, is the log of CEO compensation which is measured by cash compensation (the sum of base salary and bonus), equity-based compensation (the sum of the value of stock options and award granted during the year), or total compensation (the sum of cash compensation and equity-based compensation). For our estimation, we use pooled OLS with robust standard errors when the dependent variable is total or cash compensation, and a pooled Tobit model when the dependent variable is equity-based compensation. We estimate equity-based compensation models with Tobit to account the censoring at zero of this variable. We also include a year-specific dummy that varies across time to control for the effects of exogenous economic factors on CEO compensation during the 
sample period. A country-specific dummy, which controls for factors specific to each country, and industry-specific dummy, which controls for industry effects that influence CEO compensation are included in our regression model.

FAMILY ${ }_{i t}$ is a dummy variable for firms with controlling family shareholder, who has at least 10 percent of firm's outstanding shares, or alternatively largest shareholder owning at least 10 percent of outstanding shares is controlled by a family. This definition for family control follows Faccio and Lang (2002). We also use a dummy variable for firms with a family CEO (FAMILYCEO $O_{i t}$, that is a CEO who belongs to the controlling family. Institutional ownership, TOTINST $_{\text {it }}$, is measured by percentage of total institutional shareholdings, that is, shareholdings by institutional investors as the sum of percentages of domestic and foreign institutional shareholdings.

Following prior studies two different measures of firm performance (PERFORMANCE $\left.E_{i t}\right)$ are used: market-based performance measure, that is stock return, and accounting-based performance measure, that is ROA. Agency theory suggests that a close link between CEO compensation and firm performance would help align the interests of shareholders with those of $\mathrm{CEO}$ and therefore give incentives to the CEO to perform better. GOVERNANCE $E_{i t}$ is a set of corporate governance variables that include: board size, percentage of independent directors, CEO tenure, number of directorships held by CEO, and a dummy for board busyness.

Finally, we include the following firm-specific control variables (CONTROLVARIABLES $\left.S_{i t}\right)$ : firm size, which is measured by log of sales; growth opportunities, which is measured by sales growth. Market-to-book ratio is also added to control for growth opportunities. We control for the volatility of stock return using the standard deviation of returns as control variable. Following Hartzell and Starks (2003) and Ozkan (2010) among others, we 
use lagged explanatory variables to reduce the potential endogeneity problem in our regression models.

\subsection{Regression results}

We present the results of our baseline regression models in Table 3. Panel A shows the results for total compensation; while Panels B and C present the results for cash and equity-based compensation respectively. The results in Panel A of Table 3 show that the coefficient estimate for family control is negative and significant suggesting that while family firms might offer greater job security for the CEOs, they pay lower compensation to their CEOs. ${ }^{19}$ We observe that CEO pay is further reduced when the CEO is a member of the controlling family, as the coefficient FAMILYCEO is negative and significant in all three regressions. Family CEOs receive relatively lower compensation than professional CEOs. This evidence is consistent with the hypothesis that family ties can increase the commitment of a CEO to the firm and thus a family CEO would be less likely to leave the firm for another firm and more prone to accept a lower pay. Our results do not support the finding of Barontini and Bozzi (2009), who uses a sample of Italian firms and report that family CEOs receive excessive compensation relative to professional CEOs. In our sample of Continental European firms, we do not find any significant evidence of rent extracting by family CEOs providing excessive compensation for themselves.

Total institutional ownership has a positive and significant impact on the level of CEO compensation. Our results suggest that despite their increasing ownership in Continental European firms, institutional investors do not seem to provide monitoring for CEO compensation by putting a check on it. This finding is contrary to the results from Hartzell and Starks (2003)

\footnotetext{
${ }^{19}$ Results do not change if we use the voting rights of the controlling family instead of the dummy FAMILY.
} 
and Ozkan (2010) who find that institutional ownership has a negative and significant impact on CEO compensation in US and UK, respectively.

The results in Panel A of Table 3 show that the relationship between board size and CEO compensation is positive and significant. This finding supports the argument that larger boards can have problems with coordination, communication and monitoring the management, which can lead to higher CEO compensation. For our sample of Continental European firms larger boards seem to be less effective in providing monitoring for CEO compensation packages. Furthermore, we find a positive and significant relation between the proportion of independent directors and CEO compensation level; firms with higher proportion of independent directors offer higher level of CEO compensation. The independent directors do not seem to play a significant role in reducing managerial entrenchment. This result is in line with the findings of Ozkan (2010) who reports that non-executive directors do not perform a disciplinary function in UK companies by monitoring CEO compensation packages. We also find that firms with busy boards offer higher CEO total, cash and equity-based compensation indicating that busy boards fail to provide effective monitoring for CEO compensation packages.

The coefficient for CEO tenure is negative and generally insignificant. Thus, longer CEO tenure does not appear to increase the level of CEO compensation. We can interpret this finding as CEOs with longer tenure are not more entrenched compared to other CEOs in our sample of firms. Additionally, we find that CEOs with higher number of directorships in listed firms receive higher compensation, which is consistent with the hypothesis that higher quality CEOs demand higher compensation.

Firm performance, measured by stock return, does not have any significant impact on CEO compensation. This finding is contrary to the results from prior studies reporting positive 
and significant impact of stock return on CEO compensation for UK and US firms (Ozkan, 2010; and Hartzell and Starks, 2003). We also observe that the coefficient estimate for ROA, accounting-based measure of firm performance, is negative and weakly significant. Surprisingly, the coefficient for sales growth is negative and significant. Similar to the findings from the previous studies on CEO compensation, market-to-book ratio, which is a measure of growth opportunities, has a positive and significant impact on CEO compensation. As expected, the higher the information asymmetry, measured by STDDEVRET, the higher the CEO compensation. CEOs with an informational advantage are indeed able to entrench themselves and obtain a higher compensation. Finally, we find that firm size, measured by log of sales, has a positive and significant impact on CEO compensation.

[Table 3 about here]

We examine the cash and equity-based components of CEO pay in Panel B and C. Panel B of Table 3 reports our estimation results for the cash compensation where the coefficient for family control is always negative and significant. However, different from the results in Panel A, the coefficient of FAMILYCEO is negative and significant only in column 1, suggesting that, when it comes to the cash component of the CEO pay, family and non-family CEO in familycontrolled firms obtain similar amount of salary. Again we find a positive coefficient for institutional investor ownership. This result casts doubt on the monitoring role of these institutions. The coefficients of board characteristics and firm-specific variables are similar to those in the total compensation regressions.

Panel $\mathrm{C}$ presents the estimates of tobit models for equity-based compensation. We observe that the coefficient for family control changes from negative and significant in column 
(1) to positive and significant in column (4). However, the coefficient for FAMILYCEO is negative and significant. This indicates that the lower total compensation paid to family CEO stems from lower equity linked compensation. TOTINST retains is positive and significant coefficient. Taken together, these results highlight that families tend to reduce the equity component in the CEO pay when the CEO is a member of the family, but they give more equity incentive to their professional managers. This pay structure is consistent with the view that family CEOs in family firms do not need additional equity-based compensation to align their incentives with those of the largest shareholders. On the other hand, families tend to offer more equity-based compensation when they hire a professional manager in order to increase her effort.

Overall, the results suggest that family firms offer a lower remuneration to their CEOs than non-family firms. We also find evidence that family CEOs receive a lower compensation because they usually receive less equity-based compensation. We also find that institutional investors, far from monitoring and help reducing the CEO pay, have a positive effect on executive compensation. We now take a closer look at institutional investors in the next section.

\subsection{Domestic, foreign institutional investors and hedge funds.}

In Table 4 we examine whether the institutional investor nationality matters. We also include hedge funds to test their effect on CEO compensation. Our results show that the impact of institutional investors on CEO compensation varies depending on whether they are foreign or domestic. We observe that foreign institutional ownership has a positive and significant impact on total, cash, and equity-based CEO compensation. This finding suggests that, contrary to some anecdotal evidence, foreign institutional ownership does not seem to be playing an active role in limiting CEO compensation level. On the other hand, we find that the effect of domestic 
institutional ownership is not significant on total and cash compensation, but domestic institutional investor ownership affects equity compensation positively. Furthermore, hedge fund ownership does not have the expected impact. In fact, in column (3), hedge funds have a significant effect only on equity compensation, but the coefficient has a positive sign. The results for family control dummy and other control variables are similar to those presented in Table 3.

[Table 4 about here]

In Table 5 we consider the interaction of institutional ownership and family control to investigate whether institutional investors can play a significant monitoring role in determining CEO compensation in firms with family control. The coefficient for the interaction term between family and institutional ownership in Column 1, FAMILY*TOTINST, is positive and significant, which indicates that institutional ownership increases the CEO pay in family firms. Interestingly, this effect is limited to the cash component of the compensation. In fact, we find a negative and significant coefficient for FAMILY*TOTINST in the equity-based compensation regression. This is consistent with the view that institutional investors do not want to give more power (i.e. voting rights) to the controlling family shareholders. The interaction term FAMILYCEO*TOTINST is not significant in total and cash compensation, which indicates that institutional investors are not inclined to differentiate the pay between family members and professional managers. However, the coefficient is positive and weakly significant in the equity regression. The interaction between family control and domestic/foreign institutional ownership allows us to uncover an important distinction. While in Table 4 we find a positive effect of domestic institutional investors, which contradicts the monitoring role of these institutions, results in Table 5 offer an explanation. Domestic institutional investors do monitor and decrease the CEO pay when the 
firm is not family controlled, but they help increasing the CEO compensation when the firm is owned by a family. This pattern holds also for cash compensation, while in the equity-based compensation regressions, the interaction term between domestic institutional ownership and family control is not significant. Concerning foreign institutional investors, while the coefficient of FORINST remains positive and significant in Table 5, the interaction term FORINST*FAMILY is generally not significant. Hedge funds behave differently if they face a family or non-family firms when it comes to offer equity-based compensation. Hedge fund ownership has a positive impact on CEO pay in order to align the incentives of the CEO, but this effect is weaker in family firms. Finally, we find that the interaction between FAMILYCEO and institutional ownership is significant only in the equity-based compensation regressions. Institutional investors, both foreign and domestic, tend to decrease the equity component of the compensation package if the CEO is a family member. This is consistent with the view that institutional investors do not want that the controlling family further increases its power. Interestingly, the interaction between hedge fund ownership and FAMILYCEO is positive and significant.

\section{[Table 5 about here]}

\subsection{Family control, institutional investors, and firm performance}

In Table 6 we consider the interaction of family control with firm's stock price performance to investigate the CEO pay-for-performance link in firms with controlling family shareholders. A close link between CEO pay and performance can help aligning interests of CEOs with those of shareholders and act as a disciplinary force for CEOs to make decisions in the best interests of shareholders reducing potential CEO entrenchment. In firms with a controlling family 
shareholder CEO entrenchment can be minimal since family shareholder would have incentives to provide monitoring to minimize managerial entrenchment. Consequently, those firms with family control are likely to have less need to have a close link between CEO pay and performance as a disciplinary mechanism for reducing managerial entrenchment.

Our findings show that family control does not have any significant impact on CEO payfor-performance link, with the only exception of equity-based compensation. The coefficient estimate for the interaction term, FAMILY*RETURN, is insignificant for CEO total and cash compensation. However, it is negative and significant for equity-based compensation suggesting that family firms do not seem to use equity-based compensation to establish a positive link for CEO pay-for-performance. Similarly, the coefficient estimate for FAMILYCEO*RETURN is negative and insignificant for CEO total and cash compensation, while it is negative and significant for equity-based compensation. Thus, family CEOs do not seem to receive equitybased incentives that could help establishing a positive link between their compensation and firm performance.

\section{[Table 6 about here]}

We also examine the interaction term between institutional ownership and firm performance. Table 6 shows that institutional ownership has a positive and significant impact on CEO pay-for-performance for total compensation, cash compensation, and equity-based compensation. Thus we find some evidence of active monitoring by institutional investors, which supports the anecdotal evidence of institutional investor activism from the media. We also examine whether institutional investor nationality plays a significant role in establishing a positive link between CEO pay and performance in family firms and firms with family CEOs. 
Our results show that domestic institutional investors are associated with higher pay-performance link when we consider equity-based compensation, but they do not seem to show activism in establishing positive pay-for-performance relationship for CEO total and cash compensation. The interaction coefficient between foreign institutional ownership and return is not statistically significant. Hedge fund ownership seems to be particularly sensitive to performance. In fact the coefficient estimate for HEDGEFUND*RETURN is always positive and significant, suggesting that when hedge funds are present, the compensation tends to be significantly linked with the stock performance.

Finally, in Table 7, we examine how this pay-for-performance link changes when institutional investors hold stakes in family-controlled firms. We find that the pay-forperformance sensitivity increases with the ownership of institutional investors in family firms run by a family member (TOTINST*FAMILYCEO*RETURN).

[Table 7 about here]

Overall, we find that the equity-based component of the pay package seems more sensitive to firm performance. This effect is particularly important when domestic institutional investors and hedge funds hold equity stakes in a company. CEO compensation does not depend on stock price performance in family firms, and in these firms, CEOs are rewarded with larger equity-based compensation when the company is performing poorly. This finding suggests that there is a sort of insurance that family firms offer to their executives. 


\section{Conclusions}

Empirical analysis of the determinants of CEO compensation has been mostly done in a singlecountry context, that is, mainly the US or UK. A large number of studies have focused on firmspecific determinants of CEO compensation and how CEO compensation is related to firm performance and governance characteristics in the US companies. In this paper, we examine various aspects of CEO compensation using a large sample of 14 Continental European countries over the period from 2001 to 2008. Our main objective is to analyze the role of controlling family shareholders, institutional investors, and their interaction, in determining CEO compensation packages. Given the prevalence of concentrated ownership structures in Continental Europe where families own large, and often controlling, equity stakes in listed firms, it is important to improve our understanding of how CEO incentives and compensation packages differ from those in the US and UK, where most listed firms are widely-held and concentrated ownership by families is relatively rare.

This paper contributes to the current debate on CEO compensation in several ways. First, we perform the first cross-country analysis of CEO compensation in Continental Europe, examining how family control and institutional investors can influence CEO compensation level and pay for performance sensitivity. Second, we show that family control curbs CEO compensation, reducing CEO total compensation including both cash and equity-based compensation. We document that this effect is particularly strong in firms with family CEOs, indicating that $\mathrm{CEO}$ compensation is not used by the controlling family to expropriate wealth from minority investors. We also find that family firms tend to smooth equity-based compensation: they increase equity compensation when the firm is performing poorly, and decrease it when the stock price is increasing. 
Additionally, our results show that total institutional ownership has a positive impact on CEO pay-for-performance link for our sample firms. This finding is consistent with the results from the previous studies using data from the UK and US and reporting positive impact of institutional investors on CEO pay-for-performance link. Furthermore, we provide evidence suggesting that institutional investors partially counterbalance the negative effect of familycontrol on the level of CEO compensation, especially in family firms with professional CEOs, and increase the level of CEO compensation.

Finally, we investigate the role of hedge fund ownership on compensation. We do not observe that hedge fund's ownership has a mitigating effect on CEO compensation. However, we find that hedge fund ownership has a significant and positive impact on CEO equity-based pay for performance sensitivity. 


\section{References}

Aggarwal, R., Erel, I., Ferreira, M., Matos, P., 2009. Does Governance Travel Around the World? Evidence from Institutional Investors, Working paper.

Anderson, R. C., Reeb, D.M., 2003. Founding-family ownership and firm performance: evidence from the S\&P 500. Journal of Finance 58, 1301-1328.

Andres, C., 2008. Large shareholders and firm performance: An empirical examination of founding-family ownership. Journal of Corporate Finance 14, 431-445.

Barak, R., Cohen, S., Lauterbach, B., 2008. The effect of CEO pay on firm valuation in closely held firms. Working paper.

Barontini, R., Bozzi, S., 2009. CEO Compensation and performance in family firms. Working paper.

Barca, F., Becht, M., 2001. The Control of Corporate Europe. Oxford University Press, Oxford.

Becht, M., Franks, J., Mayer, C., Rossi, S., 2009. Returns to shareholder activism: evidence from a clinical study of the Hermes UK focus fund. Review Financial Studies 22, 3093-3129.

Becht, M., Franks, J., Grant, J., 2010. Hedge Fund Activism in Europe. ECGI - Finance Working Paper No. 283/2010. Available at SSRN: http://ssrn.com/abstract=1616340

Bennedsen, M., Nielson, K.M., Perez-Gonzalez, F., Wolfenzon, D., 2007. Inside the family firm: the role of families in succession decisions and performance. Quarterly Journal of Economics 122, 647-691.

Bertrand, M., Schoar, A., 2006. The role of family in family firms. Journal of Economic Perspectives 20, 73-96.

Block, J. H., 2008. Are CEOs in family firms paid like bureaucrats? Evidence from bayesian and frequentist analyses. Working paper.

Brav, A., Jiang, W., Partnoy, F., Thomas, R., 2008. Hedge fund activism, corporate governance, and firm performance. Journal of Finance 63, 1729-1773.

Claessens, S., Djankov, S., Fan, J.P.H., Lang, L.H.P., 2002. Disentangling the incentive and entrenchment effects of large shareholdings. Journal of Finance 57, 2741-2771.

Conyon, M.J., Fernandes, N., Ferreira, M.A., Matos, P., Murphy, K.J., 2010, The executive compensation controversy: A transatlantic analysis, working paper.

Core, J.E., Holthausen, R.W., Larcker, D.F., 1999. Corporate governance, chief executive officer compensation, and firm performance. Journal of Financial Economics 51, 371-406.

Cronqvist, H., Nilsson, M., 2003. Agency costs of controlling minority shareholders. Journal of Financial and Quantitative Analysis 38, 695-719.

Doidge, C., Karoly, G.A., Stulz, R., 2007, Why do countries matter so much for corporate governance?, Journal of Financial Economics 86, 1-39.

Elston, J.A., Goldberg, L., 2003. Executive compensation and agency costs in Germany, Journal of Banking and Finance 27, 1391-1410.

Faccio, M., Lang, L. H. P., 2002. The ultimate ownership of Western European corporations. Journal of Financial Economics 65, 365-395.

Fama, E., Jensen, M.C., 1983. Separation of ownership and control. Journal of Law and Economics 26, 301-325.

Fernandes, N. G., Ferreira, M. A., Matos, P. P., Murphy, K. J., 2009, The Pay Divide: (Why)are U.S. Top Executives Paid More? ECGI - Finance Working Paper No. 255/2009. Available at SSRN: http://ssrn.com/abstract=1341639 
Ferreira, M.A., Matos, P., 2008. The colors of investors' money: The role of institutional investors around the world. Journal of Financial Economics 88, 499-533.

Ferreira, M.A., Massa, M., Matos, P., 2010, Shareholders at the gate: Institutional investors and cross-border mergers and acquisitions, Review of Financial Studies 23, 601-644.

Ferris, S.P., Jagannathan, M., Pritchard, A.C., 2003. Too busy to mind the business? Monitoring by directors with multiple board Appointments. Journal of Finance 58, 1087-1111.

Fich, E.M., Shivdasani, A., 2006. Are busy boards effective monitors? Journal of Finance 61, 689-724.

Franks, J., Mayer, C., Volpin, P., Wagner, H.F., 2009. The Life Cycle of Family Ownership: A Comparative Study of France, Germany, Italy and the U.K. Working paper.

Gillan, S., Starks, L., 2000. Corporate governance proposals and shareholder activism: the role of institutional investors. Journal of Financial Economics 57, 275-305.

Gomez-Mejia, L.R., Larraza, M., Makri, M., 2003. The determinants of CEO compensation in family-controlled public corporations. Academy of Management Journal 46, 226-237.

Haid, A., Yurtoglu, B.B., 2006. Ownership structure and executive compensation in Germany. Working paper.

Hartzell, J.C., Starks L.T., 2003. Institutional investors and executive compensation. Journal of Finance 58, 2351-2374.

Jensen, M.C., 1993. The modern industrial revolution, exit, and the failure of internal control systems. Journal of Finance 48, 831-880.

John, K., Senbet, L.W., 1998, Corporate governance and board effectiveness, Journal of Banking and Finance 22, 371-403.

Klein, A., Zur, E., 2009. Entrepreneurial shareholder activism: hedge funds and other private investors. Journal of Finance 64, 187-229.

La Porta, R., Lopez-de Silanes, F., Shleifer, A., 1999. Corporate ownership around the world. Journal of Finance 54, 471-517.

Leuz, C., Lins, K., Warnock, F., 2009, Do foreigners invest in poorly governed firms? Review of Financial Studies 22(8), 3245-3285.

Maury, B., 2006. Family ownership and firm performance: empirical evidence from Western European corporations. Journal of Corporate Finance 12, 321-341.

McConaughy, D.L., 2000. Family CEOs vs. nonfamily CEOs in the family-controlled firm: an examination of the level and sensitivity of pay to performance. Family Business Review 13, 121-131.

Miller, D., Le Breton-Miller, I., Lester, R.H., Cannella Jr., A.A., 2007. Are family firms really superior performers? Journal of Corporate Finance 13, 829-858.

Monks, R.A.G., Minnow, N., 2008. Corporate Governance. John Wiley \& Sons, Ltd. Chichester) 2nd Ed.

Morck, R., Yeung, B., 2003. Agency problems in large family business groups. Entrepreneurship Theory \& Practice 27, 367-382.

Ozkan, N., 2010. CEO compensation and firm performance: an empirical investigation of UK panel data. European Financial Management, forthcoming.

Palmberg, J., 2009. Family control and executive compensation. Working paper.

Perez-Gonzalez, F., 2006. Inherited control and firm performance. American Economic Review 96, 1559-1588.

Shleifer, A., Vishny, R.W., 1986. Large shareholders and corporate control," Journal of Political Economy 94(3), 461-488. 
Shleifer, A., Vishny, R.W., 1997. A survey of corporate governance. Journal of Finance 52, 737783.

Tosi, H.L., Gomez-Mejia, L. R., Loughry, M.L., Werner, S., Banning, K., Katz, J., Harris, R., Silva, P. 1999. Managerial discretion, compensation strategy, and firm performance: The case for the ownership structure. In G. R. Ferris (Ed.), Research in personnel and human resource management, vol. 17: 162-208. Greenwich, CT: JAI Press.

Urzua, F.I., 2009. Too few dividends? Groups' tunneling through chair and board compensation. Journal of Corporate Finance 15, 245-256.

Villalonga, B., Amit, R., 2006. How do family ownership, control and management affect firm value? Journal of Financial Economics 80, 385-41.

Villalonga, B., Amit, R., 2009. How are U.S. family firms controlled? Review of Financial Studies 22, 3047-3091. 
Table 1: Descriptive statistics for sample

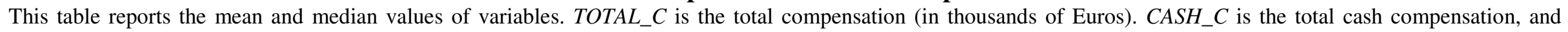

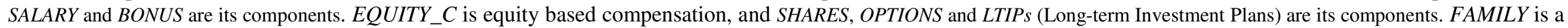

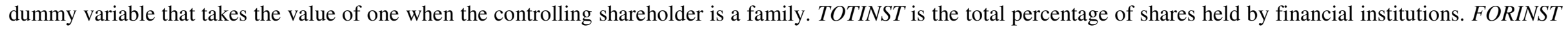

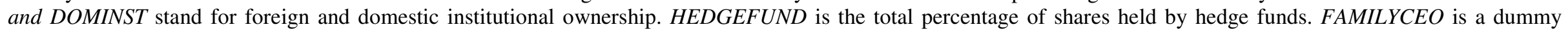

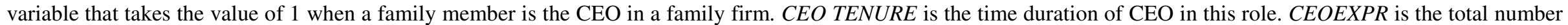

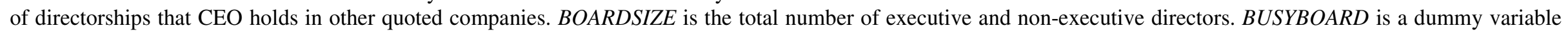

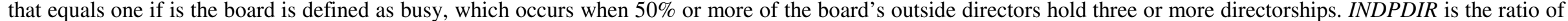

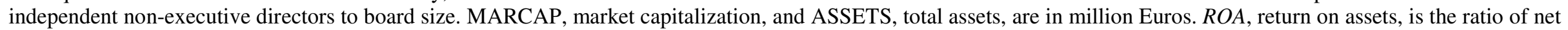

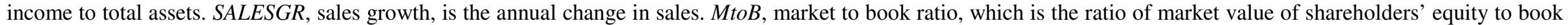

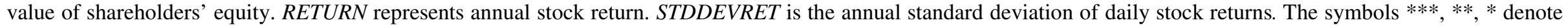
statistical significance at the $1 \%, 5 \%$, and $10 \%$ levels, respectively.

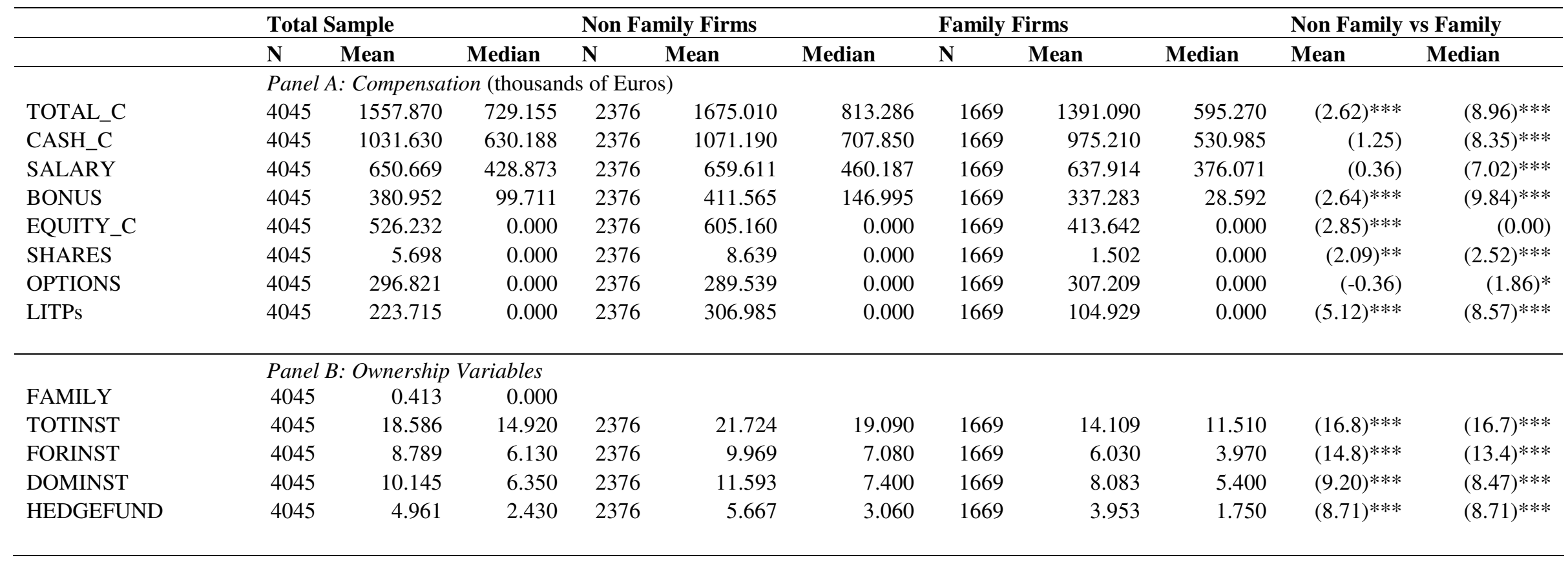


Table 1: Descriptive statistics for sample (Cont.)

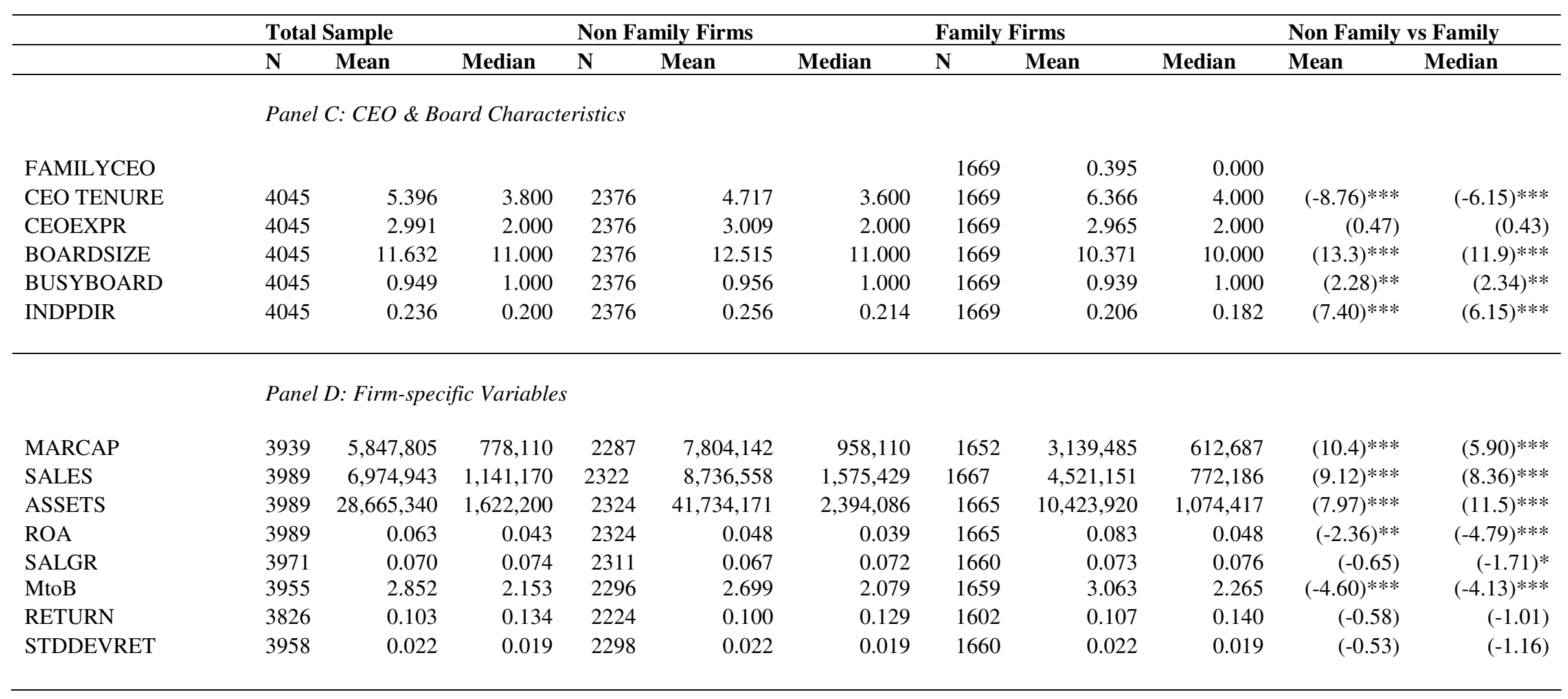


Table 2: CEO compensation and institutional ownership across years

Panel A of this table reports descriptive statistics for total compensation and components of compensation by year for Western continental European firm's CEOs. The sample period is from 2001 to 2008. TOTAL_C is the total compensation. CASH_C is the total cash compensation. EQUITY_C is equity based compensation. All is in thousands of Euros. Panel B reports descriptive statistics for the percentage of shares held by total and foreign institutional owners at Western continental European firms. The ownership is presented by country, family and non-family firms and year. The sample period is from 2001 to 2008. The ownership data is collected from Thomson One Banker ownership module. Total institutional ownership (TOTINST) and foreign institutional ownership (FORINST) are the total percentage of shares held by total and foreign financial institutions. The symbol *** denotes statistical significance at the $1 \%$ level for the tests between family and non-family firms.

Panel A: CEO compensation by year

\begin{tabular}{|c|c|c|c|c|c|c|c|}
\hline & \multicolumn{3}{|c|}{ TOTAL_C } & \multicolumn{2}{|c|}{ CASH_C } & \multicolumn{2}{|c|}{ EQUITY_C } \\
\hline & obs & Mean & Median & Mean & Median & Mean & Median \\
\hline 2001 & 255 & 1695.83 & 571.20 & 725.52 & 510.74 & 970.31 & 0.00 \\
\hline 2002 & 365 & 1474.25 & 616.24 & 1024.38 & 552.49 & 449.86 & 0.00 \\
\hline 2003 & 423 & 1309.62 & 624.42 & 840.89 & 552.31 & 468.74 & 0.00 \\
\hline 2004 & 457 & 1327.52 & 676.98 & 946.93 & 584.73 & 380.59 & 0.00 \\
\hline 2005 & 564 & 1566.99 & 670.85 & 942.38 & 578.95 & 624.61 & 0.00 \\
\hline 2006 & 631 & 1734.91 & 777.18 & 1027.44 & 669.48 & 707.47 & 0.00 \\
\hline 2007 & 683 & 1600.09 & 838.57 & 1173.11 & 743.58 & 426.98 & 0.00 \\
\hline 2008 & 667 & 1647.69 & 846.85 & 1266.20 & 770.61 & 381.49 & 0.00 \\
\hline
\end{tabular}

Panel B: Institutional ownership by year

\begin{tabular}{|c|c|c|c|c|c|c|c|}
\hline & & \multicolumn{3}{|c|}{ Total Institutional Ownership (TOTINST) } & \multicolumn{3}{|c|}{ Foreign Institutional Ownership (FORINST) } \\
\hline & obs & Full Sample & Family & Non-Family & Full Sample & Family & Non-Family \\
\hline 2001 & 255 & 19.4 & $15.1 * * *$ & 21.8 & 6.9 & $4.2 * * *$ & 8.4 \\
\hline 2002 & 365 & 17.0 & $13.3 * * *$ & 19.2 & 6.6 & $4.7 * * *$ & 7.7 \\
\hline 2003 & 423 & 16.8 & $12.5 * * *$ & 19.4 & 6.2 & $4.4 * * *$ & 7.2 \\
\hline 2004 & 457 & 16.6 & $12.8 * * *$ & 18.8 & 6.8 & $4.9 * * *$ & 7.8 \\
\hline 2005 & 564 & 16.7 & $12.4 * * *$ & 19.9 & 7.1 & $4.9 * * *$ & 8.7 \\
\hline 2006 & 631 & 17.6 & $13.2 * * *$ & 21.1 & 8.4 & $6.1 * * *$ & 10.2 \\
\hline 2007 & 683 & 21.4 & $16.0 * * *$ & 25.8 & 12.2 & $8.5 * * *$ & 15.2 \\
\hline 2008 & 667 & 21.3 & $16.2 * * *$ & 25.1 & 12.0 & $9.0 * * *$ & 14.3 \\
\hline
\end{tabular}




\section{Table 3: Family control, institutional investors and CEO compensation}

This table reports the estimates of the OLS regressions for the natural logarithm of total compensation (Panel A); for the natural logarithm of cash compensation (Panel B); and of Tobit regressions for the natural logarithm of equity compensation (Panel C). All regressions include country, industry and year fixed effects. The ownership and financial variables are lagged with respect to the dependent variable. FAMILY is a dummy variable that takes the value of one when the controlling shareholder is a family. FAMILYCEO is a dummy variable that takes the value of 1 when a family member is the CEO in a family firm. TOTINST is the sum of the percentage of stakes held by institutional investors in a given company. BOARDSIZE is the total number of executive and non-executive directors. BUSYBOARD is a dummy variable that equals one if is the board is defined as busy, which occurs when $50 \%$ or more of the board's outside directors hold three or more directorships. INDPDIR is the ratio of independent nonexecutive directors to board size. CEO TENURE is the time duration of CEO in this role. CEOEXPR is the total number of directorships that CEO has in other quoted companies as a proxy for CEO experience. RETURN represents annual stock return. $R O A$, Return on Assets, is the ratio of net income to total assets. SALESGR, sales growth is the change in sales, MtoB, market to book ratio, which is the ratio of market value of shareholders' equity to book value of shareholders' equity. STDDEVRET is the annual standard deviation of daily stock returns. LNSALES is the natural logarithm of sales. Robust standard errors are in brackets. The symbols ***,**, * denote statistical significance at the $1 \%, 5 \%$, and $10 \%$ levels, respectively.

Panel A: Total Compensation

\begin{tabular}{|c|c|c|c|c|}
\hline & (1) & (2) & (3) & (4) \\
\hline CONSTANT & $\begin{array}{c}2.893 * * * \\
{[0.423]}\end{array}$ & $\begin{array}{c}2.826 * * * \\
{[0.444]}\end{array}$ & $\begin{array}{c}2.922 * * * \\
{[0.432]}\end{array}$ & $\begin{array}{c}3.024 * * * \\
{[0.429]}\end{array}$ \\
\hline FAMILY & $\begin{array}{c}-0.195^{* * *} \\
{[0.038]}\end{array}$ & & $\begin{array}{c}-0.130 * * * \\
{[0.042]}\end{array}$ & $\begin{array}{c}-0.101 * * \\
{[0.042]}\end{array}$ \\
\hline FAMILYCEO & & $\begin{array}{c}-0.272 * * * \\
{[0.059]}\end{array}$ & $\begin{array}{c}-0.197 * * * \\
{[0.064]}\end{array}$ & $\begin{array}{c}-0.197 * * * \\
{[0.064]}\end{array}$ \\
\hline TOTINST & & & & $\begin{array}{c}0.478 * * * \\
{[0.110]}\end{array}$ \\
\hline BOARDSIZE & $\begin{array}{c}0.038 * * * \\
{[0.006]}\end{array}$ & $\begin{array}{c}0.037 * * * \\
{[0.006]}\end{array}$ & $\begin{array}{c}0.036 * * * \\
{[0.006]}\end{array}$ & $\begin{array}{c}0.034 * * * \\
{[0.006]}\end{array}$ \\
\hline BUSYBOARD & $\begin{array}{c}0.276 * * * \\
{[0.081]}\end{array}$ & $\begin{array}{c}0.269 * * * \\
{[0.083]}\end{array}$ & $\begin{array}{c}0.266 * * * \\
{[0.082]}\end{array}$ & $\begin{array}{c}0.252 * * * \\
{[0.081]}\end{array}$ \\
\hline INDPDIR & $\begin{array}{c}0.519 * * * \\
{[0.097]}\end{array}$ & $\begin{array}{c}0.516 * * * \\
{[0.099]}\end{array}$ & $\begin{array}{c}0.498 * * * * \\
{[0.098]}\end{array}$ & $\begin{array}{c}0.466 \text { **** } \\
{[0.098]}\end{array}$ \\
\hline CEO TENURE & $\begin{array}{c}-0.007 * * \\
{[0.004]}\end{array}$ & $\begin{array}{l}-0.005 \\
{[0.004]}\end{array}$ & $\begin{array}{c}-0.005 \\
{[0.003]}\end{array}$ & $\begin{array}{l}-0.005 \\
{[0.003]}\end{array}$ \\
\hline CEOEXPR & $\begin{array}{c}0.063 * * * \\
{[0.007]}\end{array}$ & $\begin{array}{c}0.065^{* * *} \\
{[0.007]}\end{array}$ & $\begin{array}{c}0.064 * * * \\
{[0.007]}\end{array}$ & $\begin{array}{c}0.065^{* * * *} \\
{[0.007]}\end{array}$ \\
\hline RETURN & $\begin{array}{l}-0.048 \\
{[0.052]}\end{array}$ & $\begin{array}{c}-0.051 \\
{[0.052]}\end{array}$ & $\begin{array}{c}-0.05 \\
{[0.052]}\end{array}$ & $\begin{array}{c}-0.044 \\
{[0.052]}\end{array}$ \\
\hline ROA & $\begin{array}{l}-0.063^{*} \\
{[0.037]}\end{array}$ & $\begin{array}{l}-0.064 * \\
{[0.036]}\end{array}$ & $\begin{array}{l}-0.061^{*} \\
{[0.037]}\end{array}$ & $\begin{array}{c}-0.069^{*} \\
{[0.037]}\end{array}$ \\
\hline SALESGR & $\begin{array}{c}-0.184 * * \\
{[0.078]}\end{array}$ & $\begin{array}{c}-0.175^{* *} \\
{[0.078]}\end{array}$ & $\begin{array}{c}-0.179 * * \\
{[0.078]}\end{array}$ & $\begin{array}{c}-0.177 * * \\
{[0.078]}\end{array}$ \\
\hline MtoB & $\begin{array}{c}0.050 * * * \\
{[0.009]}\end{array}$ & $\begin{array}{c}0.049 * * * \\
{[0.010]}\end{array}$ & $\begin{array}{c}0.050 * * * \\
{[0.010]}\end{array}$ & $\begin{array}{c}0.049 * * * * \\
{[0.009]}\end{array}$ \\
\hline STDDEVRET & $\begin{array}{c}6.073 * * * \\
{[2.217]}\end{array}$ & $\begin{array}{c}5.782 * * * \\
{[2.224]}\end{array}$ & $\begin{array}{c}5.898 * * * \\
{[2.218]}\end{array}$ & $\begin{array}{c}5.850 * * * \\
{[2.199]}\end{array}$ \\
\hline LNSALES & $\begin{array}{c}0.242 * * * \\
{[0.016]}\end{array}$ & $\begin{array}{c}0.237 * * * \\
{[0.016]}\end{array}$ & $\begin{array}{c}0.239 * * * \\
{[0.016]}\end{array}$ & $\begin{array}{c}0.233 * * * * \\
{[0.016]}\end{array}$ \\
\hline Adj. R square & 0.414 & 0.414 & 0.416 & 0.418 \\
\hline
\end{tabular}




\begin{tabular}{|c|c|c|c|c|}
\hline & (1) & (2) & (3) & (4) \\
\hline \multirow{2}{*}{ CONSTANT } & $3.431 * * *$ & $3.349 * * *$ & $3.445 * * *$ & $3.519 * * *$ \\
\hline & [0.395] & {$[0.411]$} & {$[0.400]$} & {$[0.398]$} \\
\hline \multirow[t]{2}{*}{ FAMILY } & $-0.162 * * *$ & & $-0.131 * * *$ & $-0.110 * * *$ \\
\hline & [0.034] & & [0.037] & {$[0.037]$} \\
\hline \multirow[t]{2}{*}{ FAMILYCEO } & & $-0.169 * * *$ & -0.093 & -0.093 \\
\hline & & [0.055] & {$[0.060]$} & {$[0.060]$} \\
\hline \multirow[t]{2}{*}{ TOTINST } & & & & $0.344 * * *$ \\
\hline & & & & {$[0.100]$} \\
\hline \multirow[t]{2}{*}{ BOARDSIZE } & $0.036 * * *$ & $0.036 * * *$ & $0.035 * * *$ & $0.034 * * *$ \\
\hline & {$[0.005]$} & {$[0.005]$} & [0.005] & [0.005] \\
\hline \multirow[t]{2}{*}{ BUSYBOARD } & $0.247 * * *$ & $0.245^{* * *}$ & $0.241 * * *$ & $0.232 * * *$ \\
\hline & [0.076] & [0.077] & [0.076] & {$[0.076]$} \\
\hline \multirow[t]{2}{*}{ INDPDIR } & $0.282 * * *$ & $0.290 * * *$ & $0.272 * * *$ & $0.249 * * *$ \\
\hline & [0.088] & [0.089] & [0.089] & {$[0.089]$} \\
\hline \multirow[t]{2}{*}{ CEO TENURE } & $-0.006^{*}$ & -0.005 & -0.005 & -0.005 \\
\hline & {$[0.003]$} & [0.003] & [0.003] & [0.003] \\
\hline \multirow[t]{2}{*}{ CEOEXPR } & $0.039 * * *$ & $0.040 * * *$ & $0.040 * * *$ & $0.040 * * *$ \\
\hline & [0.007] & {$[0.006]$} & [0.006] & {$[0.006]$} \\
\hline \multirow[t]{2}{*}{ RETURN } & -0.028 & -0.03 & -0.029 & -0.025 \\
\hline & [0.047] & {$[0.048]$} & [0.047] & {$[0.047]$} \\
\hline \multirow[t]{2}{*}{ ROA } & -0.031 & -0.033 & -0.03 & -0.036 \\
\hline & [0.034] & [0.034] & [0.034] & [0.034] \\
\hline \multirow[t]{2}{*}{ SALESGR } & $-0.183^{* * *}$ & $-0.177 * *$ & $-0.180^{* *}$ & $-0.179 * *$ \\
\hline & {$[0.070]$} & {$[0.070]$} & {$[0.070]$} & {$[0.070]$} \\
\hline \multirow[t]{2}{*}{ MtoB } & $0.041 * * *$ & $0.040 * * *$ & $0.041 * * *$ & $0.040 * * *$ \\
\hline & [0.008] & {$[0.008]$} & {$[0.008]$} & {$[0.008]$} \\
\hline \multirow[t]{2}{*}{ STDDEVRET } & $4.752 * *$ & $4.552^{* *}$ & $4.669^{* *}$ & $4.634 * *$ \\
\hline & [2.006] & [2.015] & [2.006] & [1.996] \\
\hline \multirow[t]{2}{*}{ LNSALES } & $0.211 * * *$ & $0.208 * * *$ & $0.209 * * *$ & $0.205^{* * *}$ \\
\hline & {$[0.015]$} & {$[0.015]$} & {$[0.015]$} & {$[0.015]$} \\
\hline Adj. R square & 0.398 & 0.396 & 0.398 & 0.4 \\
\hline Observations & 3787 & 3787 & 3787 & 3787 \\
\hline
\end{tabular}


Panel C: Equity Compensation

\begin{tabular}{|c|c|c|c|c|}
\hline & (1) & (2) & (3) & (4) \\
\hline CONSTANT & $\begin{array}{c}-57.973 * * * \\
{[0.106]}\end{array}$ & $\begin{array}{c}-57.339 * * * \\
{[0.105]}\end{array}$ & $\begin{array}{c}-57.441 * * * \\
{[0.106]}\end{array}$ & $\begin{array}{c}-56.947 * * * \\
{[0.107]}\end{array}$ \\
\hline FAMILY & $\begin{array}{c}-0.528 * * * \\
{[0.081]}\end{array}$ & & $\begin{array}{c}0.079 \\
{[0.089]}\end{array}$ & $\begin{array}{c}0.452 * * * \\
{[0.089]}\end{array}$ \\
\hline FAMILYCEO & & $\begin{array}{c}-1.992 * * * \\
{[0.079]}\end{array}$ & $\begin{array}{c}-2.038 * * * \\
{[0.094]}\end{array}$ & $\begin{array}{c}-2.002 * * * \\
{[0.094]}\end{array}$ \\
\hline TOTINST & & & & $\begin{array}{c}5.006 * * * \\
{[0.263]}\end{array}$ \\
\hline BOARDSIZE & $\begin{array}{c}0.104 * * * \\
{[0.007]}\end{array}$ & $\begin{array}{c}0.091 * * * \\
{[0.007]}\end{array}$ & $\begin{array}{c}0.092 * * * \\
{[0.007]}\end{array}$ & $\begin{array}{c}0.075^{* * * *} \\
{[0.007]}\end{array}$ \\
\hline BUSYBOARD & $\begin{array}{c}2.231 * * * \\
{[0.104]}\end{array}$ & $\begin{array}{c}2.068 * * * \\
{[0.103]}\end{array}$ & $\begin{array}{c}2.071 * * * \\
{[0.104]}\end{array}$ & $\begin{array}{c}1.994 * * * \\
{[0.104]}\end{array}$ \\
\hline INDPDIR & $\begin{array}{c}5.519 * * * \\
{[0.186]}\end{array}$ & $\begin{array}{c}5.356 * * * \\
{[0.186]}\end{array}$ & $\begin{array}{c}5.365 * * * \\
{[0.186]}\end{array}$ & $\begin{array}{c}5.097 * * * \\
{[0.187]}\end{array}$ \\
\hline CEO TENURE & $\begin{array}{c}0.01 \\
{[0.007]}\end{array}$ & $\begin{array}{c}0.034 * * * \\
{[0.008]}\end{array}$ & $\begin{array}{c}0.035^{* * * *} \\
{[0.008]}\end{array}$ & $\begin{array}{c}0.031 * * * * \\
{[0.008]}\end{array}$ \\
\hline CEOEXPR & $\begin{array}{c}0.352 * * * \\
{[0.013]}\end{array}$ & $\begin{array}{c}0.365 * * * \\
{[0.013]}\end{array}$ & $\begin{array}{c}0.366 * * * \\
{[0.013]}\end{array}$ & $\begin{array}{c}0.366 * * * \\
{[0.013]}\end{array}$ \\
\hline RETURN & $\begin{array}{c}-0.233 * * * \\
{[0.078]}\end{array}$ & $\begin{array}{c}-0.252 * * * \\
{[0.078]}\end{array}$ & $\begin{array}{c}-0.251 * * * \\
{[0.078]}\end{array}$ & $\begin{array}{c}-0.198 * * \\
{[0.078]}\end{array}$ \\
\hline ROA & $\begin{array}{c}-0.342 * * * \\
{[0.062]}\end{array}$ & $\begin{array}{c}-0.335 * * * \\
{[0.062]}\end{array}$ & $\begin{array}{c}-0.337 * * * \\
{[0.062]}\end{array}$ & $\begin{array}{c}-0.478 * * * \\
{[0.063]}\end{array}$ \\
\hline SALESGR & $\begin{array}{c}-0.388 * * * \\
{[0.093]}\end{array}$ & $\begin{array}{c}-0.360 * * * \\
{[0.093]}\end{array}$ & $\begin{array}{c}-0.361 * * * \\
{[0.093]}\end{array}$ & $\begin{array}{c}-0.332 * * * \\
{[0.094]}\end{array}$ \\
\hline MtoB & $\begin{array}{c}0.151 * * * \\
{[0.018]}\end{array}$ & $\begin{array}{c}0.144 * * * \\
{[0.018]}\end{array}$ & $\begin{array}{c}0.143 * * * \\
{[0.018]}\end{array}$ & $\begin{array}{c}0.130 * * * \\
{[0.018]}\end{array}$ \\
\hline STDDEVRET & $\begin{array}{c}33.350 * * * \\
{[3.726]}\end{array}$ & $\begin{array}{c}31.794 * * * \\
{[3.697]}\end{array}$ & $\begin{array}{c}31.733 * * * \\
{[3.725]}\end{array}$ & $\begin{array}{c}31.169 * * * \\
{[3.750]}\end{array}$ \\
\hline LNSALES & $\begin{array}{c}0.932 * * * \\
{[0.007]}\end{array}$ & $\begin{array}{c}0.891 * * * \\
{[0.007]}\end{array}$ & $\begin{array}{c}0.891 * * * \\
{[0.007]}\end{array}$ & $\begin{array}{c}0.861 * * * \\
{[0.007]}\end{array}$ \\
\hline Pseudo R square & 0.091 & 0.093 & 0.093 & 0.096 \\
\hline Observations & 3787 & 3787 & 3787 & 3787 \\
\hline
\end{tabular}


Table 4: Family control, foreign and domestic institutional blockholders, and CEO compensation

This table reports the estimates of the OLS regressions for the natural logarithm of total compensation (Panel A); for the natural logarithm of cash compensation; and of Tobit regressions for the natural logarithm of equity compensation (Panel B). All regressions include country, industry and year fixed effects. The ownership and financial variables are lagged with respect to the dependent variable. FAMILY is a dummy variable that takes the value of one when the controlling shareholder is a family. FAMILYCEO is a dummy variable that takes the value of 1 when a family member is the CEO in a family firm. FORINST and DOMINST stand for foreign and domestic institutional ownership. HEDGEFUND is the total percentage of shares held by hedge funds. BOARDSIZE is the total number of executive and non-executive directors. BUSYBOARD is a dummy variable that equals one if is the board is defined as busy, which occurs when $50 \%$ or more of the board's outside directors hold three or more directorships. INDPDIR is the ratio of independent non-executive directors to board size. CEO TENURE is the time duration of CEO in this role. CEOEXPR is the total number of directorships that CEO holds in other quoted companies as a proxy for CEO experience. RETURN represents annual stock return. ROA, Return on Assets, is the ratio of net income to total assets. SALESGR, sales growth is the change in sales, MtoB, market to book ratio, which is the ratio of market value of shareholders' equity to book value of shareholders' equity. STDDEVRET is the annual standard deviation of daily stock returns. LNSALES is the natural logarithm of sales. Robust standard errors are in brackets. The symbols ***,**,* denote statistical significance at the $1 \%, 5 \%$, and $10 \%$ levels, respectively.

Panel A: Total Compensation

\begin{tabular}{|c|c|c|c|}
\hline & (1) & (2) & (3) \\
\hline \multirow[t]{2}{*}{ CONSTANT } & $3.128 * * *$ & $2.934 * * *$ & $3.126 * * *$ \\
\hline & {$[0.426]$} & [0.433] & [0.427] \\
\hline \multirow[t]{2}{*}{ FAMILY } & $-0.076^{*}$ & $-0.113 * * *$ & $-0.075^{*}$ \\
\hline & {$[0.042]$} & {$[0.042]$} & {$[0.042]$} \\
\hline \multirow[t]{2}{*}{ FAMILYCEO } & $-0.208 * * *$ & $-0.201 * * *$ & $-0.208 * * *$ \\
\hline & [0.065] & [0.065] & [0.065] \\
\hline \multirow{2}{*}{ FORINST } & $1.521 * * *$ & & $1.497 * * *$ \\
\hline & [0.191] & & [0.203] \\
\hline \multirow[t]{2}{*}{ DOMINST } & -0.047 & & -0.051 \\
\hline & {$[0.120]$} & & [0.120] \\
\hline \multirow[t]{2}{*}{ HEDGEFUND } & & 0.831 *** & 0.086 \\
\hline & & {$[0.275]$} & [0.283] \\
\hline \multirow{2}{*}{ BOARDSIZE } & $0.034 * * *$ & $0.036 * * *$ & $0.034 * * *$ \\
\hline & {$[0.006]$} & [0.006] & [0.006] \\
\hline \multirow[t]{2}{*}{ BUSYBOARD } & $0.252 * * *$ & $0.260 * * *$ & $0.252 * * *$ \\
\hline & {$[0.081]$} & {$[0.082]$} & {$[0.081]$} \\
\hline \multirow[t]{2}{*}{ INDPDIR } & $0.421 * * *$ & $0.475 * * *$ & $0.420 * * *$ \\
\hline & [0.098] & [0.098] & [0.098] \\
\hline \multirow[t]{2}{*}{ CEO TENURE } & $-0.006^{*}$ & -0.005 & $-0.006^{*}$ \\
\hline & [0.003] & [0.003] & [0.003] \\
\hline \multirow[t]{2}{*}{ CEOEXPR } & $0.063 * * *$ & $0.063 * * *$ & $0.063 * * *$ \\
\hline & [0.007] & [0.007] & [0.007] \\
\hline \multirow[t]{2}{*}{ RETURN } & -0.041 & -0.051 & -0.041 \\
\hline & [0.052] & [0.052] & [0.052] \\
\hline \multirow[t]{2}{*}{ ROA } & -0.054 & $-0.063^{*}$ & -0.054 \\
\hline & {$[0.037]$} & [0.037] & {$[0.037]$} \\
\hline \multirow[t]{2}{*}{ SALESGR } & $-0.181 * *$ & $-0.181 * *$ & $-0.181 * *$ \\
\hline & {$[0.077]$} & {$[0.078]$} & {$[0.077]$} \\
\hline \multirow[t]{2}{*}{ MtoB } & $0.045 * * *$ & $0.049 * * *$ & $0.045^{* * *}$ \\
\hline & [0.009] & [0.009] & [0.009] \\
\hline \multirow[t]{2}{*}{ STDDEVRET } & $4.964 * *$ & $5.642 * *$ & $4.951 * *$ \\
\hline & {$[2.205]$} & [2.223] & [2.207] \\
\hline \multirow[t]{2}{*}{ LNSALES } & $0.224 * * *$ & $0.238 * * *$ & $0.224 * * *$ \\
\hline & [0.016] & [0.016] & {$[0.016]$} \\
\hline Adj. R square & 0.424 & 0.417 & 0.424 \\
\hline Observations & 3787 & 3787 & 3787 \\
\hline
\end{tabular}




\begin{tabular}{|c|c|c|c|c|c|c|}
\hline & \multicolumn{3}{|c|}{ CASH_C (Cash Compensation) } & \multicolumn{3}{|c|}{ EQUITY_C (Equity Compensation) } \\
\hline & (1) & (2) & (3) & (1) & (2) & (3) \\
\hline \multirow[t]{2}{*}{ CONSTANT } & $3.585 * * *$ & $3.449 * * *$ & $3.593 * * *$ & $-56.648 * * *$ & $-57.622 * * *$ & $-56.912 * * *$ \\
\hline & {$[0.397]$} & {$[0.400]$} & {$[0.396]$} & [0.107] & [0.106] & {$[0.107]$} \\
\hline \multirow[t]{2}{*}{ FAMILY } & $-0.094 * *$ & $-0.125 * * *$ & $-0.096 * *$ & $0.528 * * *$ & $0.307 * * *$ & $0.587 * * *$ \\
\hline & {$[0.037]$} & {$[0.038]$} & {$[0.038]$} & {$[0.089]$} & {$[0.089]$} & [0.089] \\
\hline \multirow[t]{2}{*}{ FAMILYCEO } & $-0.100 *$ & -0.095 & $-0.100 *$ & $-2.033 * * *$ & $-2.078 * * *$ & $-2.053 * * *$ \\
\hline & {$[0.060]$} & {$[0.060]$} & {$[0.060]$} & [0.094] & {$[0.093]$} & {$[0.093]$} \\
\hline \multirow[t]{2}{*}{ FORINST } & $1.019 * * *$ & & $1.092 * * *$ & $7.803 * * *$ & & $6.421 * * *$ \\
\hline & {$[0.176]$} & & {$[0.182]$} & {$[0.404]$} & & [0.429] \\
\hline \multirow{2}{*}{ DOMINST } & -0.005 & & 0.007 & $3.353 * * *$ & & $3.098 * * *$ \\
\hline & {$[0.113]$} & & {$[0.110]$} & {$[0.302]$} & & {$[0.307]$} \\
\hline \multirow[t]{2}{*}{ HEDGEFUND } & & 0.292 & -0.258 & & $8.808 * * *$ & $4.930 * * *$ \\
\hline & & {$[0.297]$} & {$[0.308]$} & & {$[0.522]$} & {$[0.566]$} \\
\hline \multirow[t]{2}{*}{ BOARDSIZE } & $0.034 * * *$ & $0.035 * * *$ & $0.034 * * *$ & $0.075 * * *$ & $0.090 * * *$ & $0.076 * * *$ \\
\hline & {$[0.005]$} & {$[0.005]$} & {$[0.005]$} & {$[0.007]$} & [0.007] & {$[0.007]$} \\
\hline \multirow[t]{2}{*}{ BUSYBOARD } & $0.232 * * *$ & $0.239 * * *$ & $0.233 * * *$ & $1.997 * * *$ & $1.967 * * *$ & $1.951 * * *$ \\
\hline & {$[0.075]$} & [0.076] & {$[0.075]$} & {$[0.105]$} & [0.104] & {$[0.105]$} \\
\hline \multirow[t]{2}{*}{ INDPDIR } & $0.220 * *$ & $0.264 * * *$ & $0.223 * *$ & $4.932 * * *$ & $5.116 * * *$ & $4.870 * * *$ \\
\hline & [0.089] & {$[0.090]$} & {$[0.090]$} & {$[0.188]$} & {$[0.188]$} & {$[0.190]$} \\
\hline \multirow[t]{2}{*}{ CEO TENURE } & $-0.006^{*}$ & -0.005 & $-0.006^{*}$ & $0.028 * * *$ & $0.033 * * *$ & $0.028 * * *$ \\
\hline & {$[0.003]$} & {$[0.003]$} & {$[0.003]$} & {$[0.008]$} & {$[0.008]$} & {$[0.008]$} \\
\hline \multirow[t]{2}{*}{ CEOEXPR } & $0.040 * * *$ & $0.040 * * *$ & $0.040 * * *$ & $0.363 * * *$ & $0.357 * * *$ & $0.359 * * *$ \\
\hline & {$[0.006]$} & {$[0.006]$} & {$[0.006]$} & {$[0.013]$} & {$[0.013]$} & {$[0.013]$} \\
\hline \multirow[t]{2}{*}{ RETURN } & -0.023 & -0.029 & -0.022 & $-0.181 * *$ & $-0.280 * * *$ & $-0.208 * * *$ \\
\hline & {$[0.047]$} & {$[0.047]$} & [0.047] & {$[0.078]$} & [0.079] & {$[0.078]$} \\
\hline \multirow[t]{2}{*}{$\mathrm{ROA}$} & -0.026 & -0.031 & -0.025 & $-0.425 * * *$ & $-0.358 * * *$ & $-0.430 * * *$ \\
\hline & {$[0.034]$} & [0.034] & {$[0.034]$} & {$[0.063]$} & {$[0.063]$} & {$[0.064]$} \\
\hline \multirow[t]{2}{*}{ SALESGR } & $-0.181 * * *$ & $-0.181 * * *$ & $-0.181 * * *$ & $-0.338 * * *$ & $-0.393 * * *$ & $-0.358 * * *$ \\
\hline & [0.070] & {$[0.070]$} & {$[0.070]$} & [0.094] & {$[0.093]$} & {$[0.094]$} \\
\hline \multirow[t]{2}{*}{ MtoB } & $0.038 * * *$ & $0.041 * * *$ & $0.038 * * *$ & $0.117 * * *$ & $0.135 * * *$ & $0.118 * * *$ \\
\hline & {$[0.008]$} & {$[0.008]$} & {$[0.008]$} & {$[0.018]$} & {$[0.018]$} & {$[0.018]$} \\
\hline \multirow[t]{2}{*}{ STDDEVRET } & $4.056 * *$ & $4.579 * *$ & $4.098 * *$ & $28.437 * * *$ & $27.042 * * *$ & $26.630 * * *$ \\
\hline & {$[2.021]$} & {$[2.010]$} & {$[2.020]$} & [3.747] & {$[3.746]$} & {$[3.766]$} \\
\hline \multirow[t]{2}{*}{ LNSALES } & $0.199 * * *$ & $0.209 * * *$ & $0.199 * * *$ & $0.831 * * *$ & $0.904 * * *$ & $0.850 * * *$ \\
\hline & [0.015] & [0.015] & [0.015] & [0.007] & {$[0.007]$} & {$[0.007]$} \\
\hline Adj. R square & 0.403 & 0.398 & 0.403 & 0.096 & 0.095 & 0.096 \\
\hline Observations & 3787 & 3787 & 3787 & 3787 & 3787 & 3787 \\
\hline
\end{tabular}


Table 5: Interactions between family control and institutional investors, and CEO compensation

This table reports the estimates of the OLS regressions for the natural logarithm of total compensation (Panel A); for the natural logarithm of cash compensation; and of Tobit regressions for the natural logarithm of equity compensation (Panel B). All regressions include country, industry and year fixed effects. The ownership and financial variables are lagged with respect to the dependent variable. FAMILY is a dummy variable that takes the value of one when the controlling shareholder is a family. FAMILYCEO is a dummy variable that takes the value of 1 when a family member is the CEO in a family firm. TOTINST is the sum of the percentage of stakes held by institutional investors in a given company. FORINST and DOMINST stand for foreign and domestic institutional ownership. HEDGEFUND is the total percentage of shares held by hedge funds. BOARDSIZE is the total number of executive and non-executive directors. BUSYBOARD is a dummy variable that equals one if is the board is defined as busy, which occurs when $50 \%$ or more of the board's outside directors hold three or more directorships. INDPDIR is the ratio of independent non-executive directors to board size. CEO TENURE is the time duration of CEO in this role. CEOEXPR is the total number of directorships that CEO has in other quoted companies as a proxy for CEO experience. RETURN represents annual stock return. ROA, Return on Assets, is the ratio of net income to total assets. SALESGR, sales growth is the change in sales, MtoB, market to book ratio, which is the ratio of market value of shareholders' equity to book value of shareholders' equity. STDDEVRET is the annual standard deviation of daily stock returns. LNSALES is the natural logarithm of sales. Robust standard errors are in brackets. The symbols $* * *, * *, *$ denote statistical significance at the $1 \%, 5 \%$, and $10 \%$ levels, respectively.

Panel A: Total Compensation

\begin{tabular}{|c|c|c|c|c|}
\hline & (1) & (2) & (3) & (4) \\
\hline \multirow[t]{2}{*}{ CONSTANT } & $3.102 * * *$ & $3.113 * * *$ & $3.243 * * *$ & $3.260 * * *$ \\
\hline & {$[0.421]$} & {$[0.432]$} & {$[0.418]$} & {$[0.430]$} \\
\hline \multirow[t]{2}{*}{ FAMILY } & $-0.274 * * *$ & $-0.188 * * *$ & $-0.282 * * *$ & $-0.197 * * *$ \\
\hline & {$[0.059]$} & {$[0.065]$} & {$[0.062]$} & {$[0.073]$} \\
\hline \multirow[t]{2}{*}{ FAMILYCEO } & & $-0.251 * *$ & & $-0.229 * *$ \\
\hline & & {$[0.101]$} & & {$[0.108]$} \\
\hline \multirow[t]{2}{*}{ TOTINST } & $0.300^{* *}$ & $0.308 * *$ & & \\
\hline & {$[0.124]$} & {$[0.124]$} & & \\
\hline \multirow[t]{2}{*}{ FAMILY*TOTINST } & $0.629 * * *$ & $0.486^{* *}$ & & \\
\hline & {$[0.216]$} & {$[0.235]$} & & \\
\hline \multirow[t]{2}{*}{ FAMILYCEO*TOTINST } & & 0.444 & & \\
\hline & & {$[0.460]$} & & \\
\hline \multirow[t]{2}{*}{ FORINST } & & & $1.389 * * *$ & $1.421 * * *$ \\
\hline & & & {$[0.220]$} & {$[0.220]$} \\
\hline \multirow[t]{2}{*}{ DOMINST } & & & $-0.286 * *$ & $-0.285^{* *}$ \\
\hline & & & {$[0.140]$} & {$[0.139]$} \\
\hline \multirow[t]{2}{*}{ HEDGEFUND } & & & -0.076 & -0.078 \\
\hline & & & {$[0.306]$} & {$[0.307]$} \\
\hline \multirow[t]{2}{*}{ FAMILY*FORINST } & & & 0.438 & 0.348 \\
\hline & & & {$[0.456]$} & {$[0.549]$} \\
\hline \multirow[t]{2}{*}{ FAMILY*DOMINST } & & & $0.801 * * *$ & $0.788 * * *$ \\
\hline & & & {$[0.218]$} & {$[0.224]$} \\
\hline \multirow[t]{2}{*}{ FAMILY* HEDGEFUND } & & & 0.563 & 0.304 \\
\hline & & & {$[0.585]$} & {$[0.737]$} \\
\hline \multirow[t]{2}{*}{ FAMILYCEO*FORINST } & & & & 0.021 \\
\hline & & & & {$[0.871]$} \\
\hline \multirow[t]{2}{*}{ FAMILYCEO*DOMINST } & & & & -0.042 \\
\hline & & & & {$[0.601]$} \\
\hline \multirow[t]{2}{*}{ FAMILYCEO*HEDGEFUND } & & & & 0.721 \\
\hline & & & & {$[1.019]$} \\
\hline
\end{tabular}




\begin{tabular}{|c|c|c|c|c|}
\hline & (1) & (2) & (3) & (4) \\
\hline \multirow[t]{2}{*}{ BOARDSIZE } & $0.035^{* * *}$ & $0.034 * * *$ & $0.035^{* * *}$ & $0.033 * * *$ \\
\hline & {$[0.006]$} & {$[0.006]$} & {$[0.006]$} & [0.006] \\
\hline \multirow[t]{2}{*}{ BUSYBOARD } & $0.260 * * *$ & $0.250 * * *$ & $0.260 * * *$ & $0.247 * * *$ \\
\hline & {$[0.080]$} & {$[0.081]$} & {$[0.080]$} & {$[0.080]$} \\
\hline \multirow[t]{2}{*}{ INDPDIR } & $0.484 * * *$ & $0.464 * * *$ & $0.440 * * *$ & $0.417 * * *$ \\
\hline & {$[0.097]$} & {$[0.098]$} & [0.097] & {$[0.098]$} \\
\hline \multirow[t]{2}{*}{ CEO TENURE } & $-0.007 * *$ & -0.006 & $-0.008 * *$ & $-0.006^{*}$ \\
\hline & {$[0.003]$} & {$[0.003]$} & {$[0.003]$} & {$[0.003]$} \\
\hline \multirow[t]{2}{*}{ CEOEXPR } & $0.064 * * *$ & $0.065 * * *$ & $0.062 * * *$ & $0.064 * * *$ \\
\hline & {$[0.007]$} & {$[0.007]$} & {$[0.007]$} & [0.007] \\
\hline \multirow[t]{2}{*}{ RETURN } & -0.04 & -0.041 & -0.037 & -0.038 \\
\hline & {$[0.052]$} & {$[0.052]$} & {$[0.052]$} & {$[0.052]$} \\
\hline \multirow[t]{2}{*}{ ROA } & $-0.073 *$ & $-0.072 *$ & -0.059 & -0.058 \\
\hline & {$[0.037]$} & {$[0.037]$} & {$[0.037]$} & {$[0.037]$} \\
\hline \multirow[t]{2}{*}{ SALESGR } & $-0.179 * *$ & $-0.173 * *$ & $-0.183 * *$ & $-0.176 * *$ \\
\hline & {$[0.078]$} & {$[0.078]$} & {$[0.077]$} & {$[0.077]$} \\
\hline \multirow[t]{2}{*}{ MtoB } & $0.049 * * *$ & $0.048 * * *$ & $0.045 * * *$ & $0.045 * * *$ \\
\hline & [0.009] & [0.009] & [0.009] & [0.009] \\
\hline \multirow[t]{2}{*}{ STDDEVRET } & $5.823 * * *$ & $5.645^{* *}$ & $4.881 * *$ & $4.753 * *$ \\
\hline & [2.204] & [2.208] & [2.213] & [2.212] \\
\hline \multirow[t]{2}{*}{ LNSALES } & $0.234 * * *$ & $0.232 * * *$ & $0.225^{* * *}$ & $0.222 * * *$ \\
\hline & {$[0.016]$} & {$[0.016]$} & {$[0.016]$} & {$[0.016]$} \\
\hline Adj. R-square & 0.417 & 0.419 & 0.423 & 0.424 \\
\hline Observations & 3787 & 3787 & 3787 & 3787 \\
\hline
\end{tabular}




\begin{tabular}{|c|c|c|c|c|c|c|c|c|}
\hline & \multicolumn{4}{|c|}{ CASH_C (Cash Compensation) } & \multicolumn{4}{|c|}{ EQUITY_C (Equity Compensation) } \\
\hline & (1) & (2) & (3) & (4) & (1) & (2) & (3) & (4) \\
\hline \multirow[t]{2}{*}{ CONSTANT } & $3.640 * * *$ & $3.646 * * *$ & $3.746 * * *$ & $3.759 * * *$ & $-57.742 * * *$ & $-57.296^{* * *}$ & $-57.635 * * *$ & $-57.367 * * *$ \\
\hline & [0.394] & [0.399] & {$[0.392]$} & [0.397] & [0.107] & [0.107] & {$[0.108]$} & [0.107] \\
\hline \multirow[t]{2}{*}{ FAMILY } & $-0.279 * * *$ & $-0.241 * * *$ & $-0.296^{* * *}$ & $-0.259 * * *$ & 0.149 & $0.861 * * *$ & $0.239^{* *}$ & $1.150 * * *$ \\
\hline & {$[0.053]$} & {$[0.059]$} & {$[0.057]$} & {$[0.067]$} & [0.096] & {$[0.105]$} & [0.107] & [0.114] \\
\hline \multirow[t]{2}{*}{ FAMILYCEO } & & -0.107 & & -0.088 & & $-2.215 * * *$ & & $-2.486^{* * *}$ \\
\hline & & [0.096] & & [0.102] & & {$[0.139]$} & & [0.164] \\
\hline \multirow{2}{*}{ TOTINST } & 0.116 & 0.12 & & & $5.475^{* * *}$ & $5.511 * * *$ & & \\
\hline & {$[0.113]$} & [0.114] & & & {$[0.268]$} & [0.268] & & \\
\hline \multirow[t]{2}{*}{ FAMILY*TOTINST } & $0.800^{* * *}$ & $0.745 * * *$ & & & $-1.625 * * *$ & $-2.302 * * *$ & & \\
\hline & [0.195] & {$[0.211]$} & & & {$[0.374]$} & [0.407] & & \\
\hline \multirow[t]{2}{*}{ FAMILYCEO*TOTINST } & & 0.162 & & & & $1.388^{*}$ & & \\
\hline & & {$[0.435]$} & & & & {$[0.756]$} & & \\
\hline \multirow[t]{2}{*}{ FORINST } & & & $0.909^{* * *}$ & $0.927 * * *$ & & & $6.581 * * *$ & $6.888 * * *$ \\
\hline & & & {$[0.198]$} & [0.199] & & & [0.441] & {$[0.440]$} \\
\hline \multirow[t]{2}{*}{ DOMINST } & & & $-0.246^{*}$ & $-0.247^{*}$ & & & $3.424 * * *$ & $3.339 * * *$ \\
\hline & & & {$[0.130]$} & {$[0.130]$} & & & {$[0.328]$} & {$[0.326]$} \\
\hline \multirow[t]{2}{*}{ HEDGEFUND } & & & -0.41 & -0.409 & & & $5.280 * * *$ & $5.148 * * *$ \\
\hline & & & {$[0.343]$} & {$[0.343]$} & & & {$[0.596]$} & {$[0.598]$} \\
\hline \multirow{2}{*}{ FAMILY*FORINST } & & & $0.799 *$ & 0.723 & & & -1.156 & -0.524 \\
\hline & & & {$[0.410]$} & {$[0.483]$} & & & {$[0.795]$} & [0.867] \\
\hline \multirow[t]{2}{*}{ FAMILY*DOMINST } & & & $0.828 * * *$ & $0.886 * * *$ & & & -0.535 & 0.595 \\
\hline & & & {$[0.197]$} & {$[0.201]$} & & & {$[0.476]$} & [0.494] \\
\hline \multirow[t]{2}{*}{ FAMILY* HEDGEFUND } & & & 0.581 & 0.427 & & & $-2.726^{* *}$ & $-15.262 * * *$ \\
\hline & & & {$[0.560]$} & {$[0.661]$} & & & [1.137] & {$[1.378]$} \\
\hline \multirow[t]{2}{*}{ FAMILYCEO*FORINST } & & & & 0.138 & & & & $-6.235^{* * *}$ \\
\hline & & & & [0.807] & & & & {$[1.537]$} \\
\hline \multirow[t]{2}{*}{ FAMILYCEO*DOMINST } & & & & -0.368 & & & & $-4.620 * * *$ \\
\hline & & & & {$[0.575]$} & & & & [1.316] \\
\hline \multirow[t]{2}{*}{ FAMILYCEO*HEDGEFUND } & & & & 0.366 & & & & $30.760 * * *$ \\
\hline & & & & {$[0.955]$} & & & & {$[1.838]$} \\
\hline
\end{tabular}




\begin{tabular}{|c|c|c|c|c|c|c|c|c|}
\hline & \multicolumn{4}{|c|}{ CASH_C (Cash Compensation) } & \multicolumn{4}{|c|}{ EQUITY_C (Equity Compensation) } \\
\hline & (1) & $(2)$ & (3) & (4) & (1) & (2) & (3) & (4) \\
\hline \multirow[t]{2}{*}{ BOARDSIZE } & $0.034 * * *$ & $0.033 * * *$ & $0.034 * * *$ & $0.033 * * *$ & $0.090 * * *$ & $0.078 * * *$ & $0.091 * * *$ & $0.075^{* * *}$ \\
\hline & {$[0.005]$} & {$[0.005]$} & {$[0.005]$} & {$[0.005]$} & {$[0.007]$} & {$[0.007]$} & {$[0.007]$} & {$[0.007]$} \\
\hline \multirow[t]{2}{*}{ BUSYBOARD } & $0.234 * * *$ & $0.229 * * *$ & $0.234 * * *$ & $0.229 * * *$ & $2.136 * * *$ & $1.977 * * *$ & $2.100 * * *$ & $1.818 * * *$ \\
\hline & {$[0.075]$} & {$[0.075]$} & {$[0.074]$} & {$[0.075]$} & {$[0.105]$} & {$[0.104]$} & {$[0.105]$} & {$[0.105]$} \\
\hline \multirow[t]{2}{*}{ INDPDIR } & $0.256 * * *$ & $0.247 * * *$ & $0.231 * * *$ & $0.221 * *$ & $5.261 * * *$ & $5.106 * * *$ & $5.036^{* * *}$ & $4.873 * * *$ \\
\hline & {$[0.088]$} & [0.089] & {$[0.088]$} & [0.089] & [0.187] & [0.187] & {$[0.190]$} & {$[0.190]$} \\
\hline \multirow[t]{2}{*}{ CEO TENURE } & $-0.006 * *$ & $-0.006^{*}$ & $-0.007 * *$ & $-0.006 * *$ & 0.008 & $0.032 * * *$ & 0.004 & $0.024 * * *$ \\
\hline & {$[0.003]$} & {$[0.003]$} & {$[0.003]$} & {$[0.003]$} & {$[0.007]$} & {$[0.008]$} & {$[0.008]$} & {$[0.008]$} \\
\hline \multirow[t]{2}{*}{ CEOEXPR } & $0.041 * * *$ & $0.041 * * *$ & $0.040 * * *$ & $0.040 * * *$ & $0.350 * * *$ & $0.364 * * *$ & $0.344 * * *$ & $0.351^{* * *}$ \\
\hline & {$[0.006]$} & {$[0.006]$} & {$[0.006]$} & {$[0.006]$} & {$[0.013]$} & {$[0.013]$} & {$[0.013]$} & {$[0.013]$} \\
\hline \multirow[t]{2}{*}{ RETURN } & -0.022 & -0.022 & -0.018 & -0.02 & $-0.179 * *$ & $-0.195 * *$ & $-0.189 * *$ & $-0.143^{*}$ \\
\hline & {$[0.047]$} & {$[0.047]$} & {$[0.047]$} & {$[0.048]$} & {$[0.078]$} & {$[0.078]$} & {$[0.079]$} & {$[0.078]$} \\
\hline \multirow[t]{2}{*}{ ROA } & -0.04 & -0.039 & -0.029 & -0.028 & $-0.482 * * *$ & $-0.478 * * *$ & $-0.438 * * *$ & $-0.455 * * *$ \\
\hline & {$[0.034]$} & {$[0.034]$} & {$[0.034]$} & {$[0.034]$} & {$[0.064]$} & {$[0.063]$} & {$[0.065]$} & {$[0.064]$} \\
\hline \multirow[t]{2}{*}{ SALESGR } & $-0.177 * *$ & $-0.175^{* *}$ & $-0.180 * * *$ & $-0.177 * *$ & $-0.363 * * *$ & $-0.334 * * *$ & $-0.374 * * *$ & $-0.365 * * *$ \\
\hline & {$[0.070]$} & {$[0.070]$} & {$[0.069]$} & {$[0.070]$} & [0.094] & {$[0.094]$} & {$[0.095]$} & [0.094] \\
\hline \multirow[t]{2}{*}{ MtoB } & $0.040 * * *$ & $0.040 * * *$ & $0.038 * * *$ & $0.037 * * *$ & $0.136 * * *$ & $0.127 * * *$ & $0.126^{* * *}$ & $0.118^{* * *}$ \\
\hline & {$[0.008]$} & {$[0.008]$} & {$[0.008]$} & {$[0.008]$} & {$[0.018]$} & {$[0.018]$} & {$[0.018]$} & {$[0.018]$} \\
\hline \multirow[t]{2}{*}{ STDDEVRET } & $4.460 * *$ & $4.382 * *$ & $3.878^{*}$ & $3.811^{*}$ & $33.467 * * *$ & $31.967 * * *$ & $28.882 * * *$ & $30.214 * * *$ \\
\hline & [2.003] & [2.003] & {$[2.030]$} & [2.028] & {$[3.753]$} & {$[3.751]$} & {$[3.773]$} & [3.762] \\
\hline \multirow[t]{2}{*}{ LNSALES } & $0.204 * * *$ & $0.203 * * *$ & $0.197 * * *$ & $0.196 * * *$ & $0.905 * * *$ & $0.868^{* * *}$ & $0.893 * * *$ & $0.871^{* * *}$ \\
\hline & {$[0.015]$} & {$[0.015]$} & {$[0.015]$} & {$[0.015]$} & [0.007] & [0.007] & {$[0.007]$} & {$[0.007]$} \\
\hline Adj. R-square & 0.401 & 0.401 & 0.404 & 0.404 & 0.094 & 0.096 & 0.095 & 0.097 \\
\hline Observations & 3787 & 3787 & 3787 & 3787 & 3787 & 3787 & 3787 & 3787 \\
\hline
\end{tabular}


Table 6: Effect of family control and institutional investors on CEO pay-for-performance link

This table reports the estimates of the OLS regressions for the natural logarithm of total compensation (Panel A); for the natural logarithm of cash compensation; and of Tobit regressions for the natural logarithm of equity compensation (Panel B). All regressions include country, industry and year fixed effects. The ownership and financial variables are lagged with respect to the dependent variable. FAMILY is a dummy variable that takes the value of one when the controlling shareholder is a family. FAMILYCEO is a dummy variable that takes the value of 1 when a family member is the CEO in a family firm. TOTINST is the sum of the percentage of stakes held by institutional investors in a given company. FORINST and DOMINST stand for foreign and domestic institutional ownership. HEDGEFUND is the total percentage of shares held by hedge funds. BOARDSIZE is the total number of executive and non-executive directors. BUSYBOARD is a dummy variable that equals one if is the board is defined as busy, which occurs when $50 \%$ or more of the board's outside directors hold three or more directorships. INDPDIR is the ratio of independent non-executive directors to board size. CEO TENURE is the time duration of CEO in this role. CEOEXPR is the total number of directorships that CEO has in other quoted companies as a proxy for CEO experience. RETURN represents annual stock return. ROA, Return on Assets, is the ratio of net income to total assets. SALESGR, sales growth is the change in sales, MtoB, market to book ratio, is the ratio of market value of shareholders' equity to book value of shareholders' equity. STDDEVRET is the annual standard deviation of daily stock returns. LNSALES is the natural logarithm of sales. Robust standard errors are in brackets. The symbols ***, **, * denote statistical significance at the $1 \%, 5 \%$, and $10 \%$ levels, respectively.

Panel A: Total Compensation

\begin{tabular}{|c|c|c|c|c|c|}
\hline & (1) & (2) & (3) & (4) & (5) \\
\hline \multirow[t]{2}{*}{ CONSTANT } & $2.890 * * *$ & $2.907 * * *$ & $3.038 * * *$ & $3.126^{* * *}$ & $2.943 * * *$ \\
\hline & {$[0.423]$} & {$[0.433]$} & {$[0.429]$} & {$[0.427]$} & {$[0.434]$} \\
\hline \multirow[t]{2}{*}{ FAMILY } & $-0.187 * * *$ & $-0.134 * * *$ & $-0.099 * *$ & $-0.076^{*}$ & $-0.112 * * *$ \\
\hline & {$[0.039]$} & {$[0.043]$} & {$[0.042]$} & {$[0.042]$} & {$[0.042]$} \\
\hline \multirow[t]{2}{*}{ FAMILY*RETURN } & -0.074 & 0.022 & & & \\
\hline & {$[0.089]$} & [0.107] & & & \\
\hline \multirow[t]{2}{*}{ FAMILYCEO } & & $-0.173 * * *$ & $-0.196 * * *$ & $-0.208 * * *$ & $-0.199 * * *$ \\
\hline & & {$[0.065]$} & [0.064] & [0.065] & [0.064] \\
\hline \multirow[t]{2}{*}{ FAMILYCEO*RETURN } & & -0.230 & & & \\
\hline & & [0.144] & & & \\
\hline \multirow[t]{2}{*}{ TOTINST } & & & $0.440 * * *$ & & \\
\hline & & & {$[0.112]$} & & \\
\hline \multirow[t]{2}{*}{ TOTINST*RETURN } & & & $0.422^{*}$ & & \\
\hline & & & {$[0.255]$} & & \\
\hline \multirow[t]{2}{*}{ FORINST } & & & & $1.517 * * *$ & \\
\hline & & & & [0.192] & \\
\hline \multirow{2}{*}{ FORINST*RETURN } & & & & 0.001 & \\
\hline & & & & {$[0.006]$} & \\
\hline \multirow[t]{2}{*}{ DOMINST } & & & & -0.040 & \\
\hline & & & & {$[0.120]$} & \\
\hline \multirow[t]{2}{*}{ DOMINST*RETURN } & & & & -0.001 & \\
\hline & & & & {$[0.002]$} & \\
\hline \multirow[t]{2}{*}{ HEDGEFUND } & & & & & $0.645^{* *}$ \\
\hline & & & & & {$[0.282]$} \\
\hline \multirow[t]{2}{*}{ HEDGEFUND*RETURN } & & & & & $1.365^{* *}$ \\
\hline & & & & & {$[0.566]$} \\
\hline
\end{tabular}




\begin{tabular}{|c|c|c|c|c|c|}
\hline & (1) & (2) & (3) & (4) & (5) \\
\hline \multirow[t]{2}{*}{ BOARDSIZE } & $0.038 * * *$ & $0.036^{* * *}$ & $0.034 * * *$ & $0.034 * * *$ & $0.036^{* * *}$ \\
\hline & {$[0.006]$} & {$[0.006]$} & [0.006] & [0.006] & {$[0.006]$} \\
\hline \multirow{2}{*}{ BUSYBOARD } & $0.276^{* * *}$ & $0.263 * * *$ & $0.253^{* * *}$ & $0.252 * * *$ & $0.256^{* * *}$ \\
\hline & [0.082] & {$[0.082]$} & {$[0.082]$} & [0.081] & {$[0.082]$} \\
\hline \multirow[t]{2}{*}{ INDPDIR } & $0.519 * * *$ & $0.497 * * *$ & $0.466^{* * *}$ & $0.420 * * *$ & $0.469 * * *$ \\
\hline & [0.097] & [0.098] & {$[0.098]$} & [0.098] & {$[0.098]$} \\
\hline \multirow{2}{*}{ CEO TENURE } & $-0.007 * *$ & -0.005 & -0.005 & $-0.006^{*}$ & -0.005 \\
\hline & {$[0.004]$} & {$[0.003]$} & [0.003] & {$[0.003]$} & {$[0.003]$} \\
\hline \multirow[t]{2}{*}{ CEOEXPR } & $0.063 * * *$ & $0.064 * * *$ & $0.065 * * *$ & $0.063 * * *$ & $0.064 * * *$ \\
\hline & {$[0.007]$} & [0.007] & [0.007] & {$[0.007]$} & {$[0.007]$} \\
\hline \multirow[t]{2}{*}{ RETURN } & -0.014 & -0.017 & -0.12 & -0.036 & $-0.122 *$ \\
\hline & [0.060] & {$[0.060]$} & [0.076] & {$[0.061]$} & {$[0.066]$} \\
\hline \multirow[t]{2}{*}{ ROA } & $-0.065^{*}$ & $-0.064^{*}$ & $-0.071 *$ & -0.053 & $-0.072 *$ \\
\hline & {$[0.037]$} & [0.037] & [0.037] & {$[0.037]$} & [0.037] \\
\hline \multirow[t]{2}{*}{ SALESGR } & $-0.184^{* *}$ & $-0.177 * *$ & $-0.176^{* *}$ & $-0.179 * *$ & $-0.180^{* *}$ \\
\hline & {$[0.078]$} & {$[0.078]$} & {$[0.078]$} & {$[0.077]$} & {$[0.078]$} \\
\hline \multirow[t]{2}{*}{ MtoB } & $0.050 * * *$ & $0.050 * * *$ & $0.049 * * *$ & $0.045^{* * *}$ & $0.049 * * *$ \\
\hline & [0.009] & {$[0.010]$} & {$[0.009]$} & {$[0.009]$} & {$[0.009]$} \\
\hline \multirow[t]{2}{*}{ STDDEVRET } & $6.106^{* * *}$ & $5.885^{* * *}$ & $5.875 * * *$ & $4.970^{* *}$ & $5.494 * *$ \\
\hline & {$[2.216]$} & {$[2.214]$} & [2.193] & [2.211] & {$[2.231]$} \\
\hline \multirow[t]{2}{*}{ LNSALES } & $0.242 * * *$ & $0.239 * * *$ & $0.232 * * *$ & $0.224 * * *$ & $0.238 * * *$ \\
\hline & {$[0.016]$} & {$[0.016]$} & {$[0.016]$} & {$[0.016]$} & {$[0.016]$} \\
\hline Adj. R-square & 0.414 & 0.416 & 0.418 & 0.423 & 0.417 \\
\hline Observations & 3787 & 3787 & 3787 & 3787 & 3787 \\
\hline
\end{tabular}


Panel B: Cash and Equity Compensation

\begin{tabular}{|c|c|c|c|c|c|c|c|c|c|c|}
\hline & \multicolumn{5}{|c|}{ CASH_C (Cash Compensation) } & \multicolumn{5}{|c|}{ EQUITY_C (Equity Compensation) } \\
\hline & (1) & $(2)$ & (3) & (4) & (5) & (1) & $(2)$ & (3) & (4) & (5) \\
\hline \multirow[t]{2}{*}{ CONSTANT } & $3.431 * * *$ & $3.436 * * *$ & $3.529 * * *$ & $3.584 * * *$ & $3.456^{* * *}$ & $-58.02 * * *$ & $-57.53 * * *$ & $-56.79 * * *$ & $-56.61 * * *$ & $-58.02 * * *$ \\
\hline & {$[0.395]$} & {$[0.400]$} & {$[0.398]$} & {$[0.397]$} & {$[0.400]$} & {$[0.106]$} & {$[0.106]$} & {$[0.107]$} & {$[0.107]$} & {$[0.106]$} \\
\hline \multirow[t]{2}{*}{ FAMILY } & $-0.162 * * *$ & $-0.140 * * *$ & $-0.109 * * *$ & $-0.094 * *$ & $-0.125 * * *$ & $-0.385^{* * *}$ & $0.198 * *$ & $0.477 * * *$ & $0.523 * * *$ & $-0.385 * * *$ \\
\hline & {$[0.035]$} & [0.039] & {$[0.037]$} & {$[0.037]$} & {$[0.038]$} & {$[0.081]$} & {$[0.090]$} & [0.089] & {$[0.089]$} & {$[0.081]$} \\
\hline \multirow[t]{2}{*}{ FAMILY*RETURN } & 0.001 & 0.076 & & & & $-1.478 * * *$ & $-1.268 * * *$ & & & \\
\hline & {$[0.080]$} & {$[0.095]$} & & & & {$[0.124]$} & {$[0.161]$} & & & \\
\hline \multirow[t]{2}{*}{ FAMILYCEO } & & -0.074 & -0.093 & $-0.101 *$ & -0.093 & & $-1.986^{* * *}$ & $-1.999 * * *$ & $-2.028 * * *$ & $-2.061 * * *$ \\
\hline & & {$[0.060]$} & {$[0.060]$} & {$[0.060]$} & {$[0.060]$} & & {$[0.096]$} & {$[0.094]$} & {$[0.094]$} & {$[0.093]$} \\
\hline \multirow[t]{2}{*}{ FAMILYCEO*RETURN } & & -0.180 & & & & & $-0.568 * * *$ & & & \\
\hline & & {$[0.129]$} & & & & & [0.197] & & & \\
\hline \multirow[t]{2}{*}{ TOTINST } & & & $0.316^{* * *}$ & & & & & $4.551 * * *$ & & \\
\hline & & & {$[0.102]$} & & & & & {$[0.266]$} & & \\
\hline \multirow[t]{2}{*}{ TOTINST*RETURN } & & & 0.300 & & & & & $5.006 * * *$ & & \\
\hline & & & {$[0.229]$} & & & & & {$[0.417]$} & & \\
\hline \multirow[t]{2}{*}{ FORINST } & & & & $1.019 * * *$ & & & & & $7.872 * * *$ & \\
\hline & & & & {$[0.174]$} & & & & & {$[0.405]$} & \\
\hline \multirow[t]{2}{*}{ FORINST*RETURN } & & & & 0.000 & & & & & $-0.020 * * *$ & \\
\hline & & & & {$[0.006]$} & & & & & {$[0.006]$} & \\
\hline \multirow[t]{2}{*}{ DOMINST } & & & & 0.009 & & & & & $3.271^{* * *}$ & \\
\hline & & & & [0.109] & & & & & {$[0.307]$} & \\
\hline \multirow[t]{2}{*}{ DOMINST*RETURN } & & & & -0.002 & & & & & $0.010 * * *$ & \\
\hline & & & & {$[0.003]$} & & & & & {$[0.003]$} & \\
\hline \multirow[t]{2}{*}{ HEDGEFUND } & & & & & 0.160 & & & & & $7.578 * * *$ \\
\hline & & & & & {$[0.291]$} & & & & & {$[0.543]$} \\
\hline \multirow[t]{2}{*}{ HEDGEFUND*RETURN } & & & & & $0.971^{*}$ & & & & & $8.489 * * *$ \\
\hline & & & & & {$[0.545]$} & & & & & {$[0.957]$} \\
\hline
\end{tabular}




\begin{tabular}{|c|c|c|c|c|c|c|c|c|c|c|}
\hline & \multicolumn{5}{|c|}{ CASH_C (Cash Compensation) } & \multicolumn{5}{|c|}{ EQUITY_C (Equity Compensation) } \\
\hline & (1) & (2) & (3) & (4) & (5) & (1) & (2) & (3) & (4) & (5) \\
\hline \multirow[t]{2}{*}{ BOARDSIZE } & $0.036 * * *$ & $0.035^{* * *}$ & $0.034 * * *$ & $0.034 * * *$ & $0.035 * * *$ & $0.103 * * *$ & $0.090 * * *$ & $0.075 * * *$ & $0.075 * * *$ & $0.089 * * *$ \\
\hline & {$[0.005]$} & {$[0.005]$} & [0.005] & {$[0.005]$} & {$[0.005]$} & {$[0.007]$} & {$[0.007]$} & {$[0.007]$} & {$[0.007]$} & {$[0.007]$} \\
\hline \multirow[t]{2}{*}{ BUSYBOARD } & $0.247 * * *$ & $0.240 * * *$ & $0.232 * * *$ & $0.231 * * *$ & $0.237 * * *$ & $2.206 * * *$ & $2.038 * * *$ & $1.994 * * *$ & $1.997 * * *$ & $1.940 * * *$ \\
\hline & {$[0.076]$} & {$[0.076]$} & {$[0.076]$} & {$[0.075]$} & {$[0.076]$} & [0.104] & [0.104] & {$[0.104]$} & {$[0.105]$} & [0.104] \\
\hline \multirow[t]{2}{*}{ INDPDIR } & $0.282 * * *$ & $0.271 * * *$ & $0.249 * * *$ & $0.219 * *$ & $0.260 * * *$ & $5.551 * * *$ & $5.393 * * *$ & $5.127 * * *$ & $4.933 * * *$ & $5.093 * * *$ \\
\hline & {$[0.088]$} & [0.089] & {$[0.089]$} & {$[0.089]$} & {$[0.090]$} & {$[0.186]$} & {$[0.186]$} & [0.187] & {$[0.188]$} & {$[0.188]$} \\
\hline \multirow[t]{2}{*}{ CEO TENURE } & $-0.006^{*}$ & -0.005 & -0.005 & $-0.006^{*}$ & -0.005 & 0.009 & $0.034 * * *$ & $0.031 * * *$ & $0.028 * * *$ & $0.033^{* * *}$ \\
\hline & {$[0.003]$} & {$[0.003]$} & [0.003] & {$[0.003]$} & {$[0.003]$} & {$[0.007]$} & {$[0.008]$} & {$[0.008]$} & {$[0.008]$} & {$[0.008]$} \\
\hline \multirow[t]{2}{*}{ CEOEXPR } & $0.039 * * *$ & $0.040 * * *$ & $0.041 * * *$ & $0.040 * * *$ & $0.040 * * *$ & $0.352 * * *$ & $0.366^{* * *}$ & $0.368 * * *$ & $0.362 * * *$ & $0.359 * * *$ \\
\hline & {$[0.007]$} & {$[0.006]$} & {$[0.006]$} & {$[0.006]$} & [0.007] & {$[0.013]$} & {$[0.013]$} & {$[0.013]$} & {$[0.013]$} & {$[0.013]$} \\
\hline \multirow[t]{2}{*}{ RETURN } & -0.029 & -0.03 & -0.079 & -0.01 & -0.08 & $0.411 * * *$ & $0.382 * * *$ & $-1.159 * * *$ & $-0.170^{*}$ & $-0.720 * * *$ \\
\hline & {$[0.055]$} & {$[0.055]$} & {$[0.070]$} & {$[0.058]$} & {$[0.060]$} & {$[0.109]$} & {$[0.114]$} & [0.114] & {$[0.093]$} & {$[0.097]$} \\
\hline \multirow[t]{2}{*}{ ROA } & -0.031 & -0.031 & -0.037 & -0.025 & -0.037 & $-0.386 * * *$ & $-0.379 * * *$ & $-0.492 * * *$ & $-0.437 * * *$ & $-0.401 * * *$ \\
\hline & {$[0.034]$} & {$[0.034]$} & {$[0.034]$} & {$[0.034]$} & {$[0.034]$} & {$[0.064]$} & {$[0.064]$} & {$[0.066]$} & {$[0.064]$} & {$[0.065]$} \\
\hline \multirow[t]{2}{*}{ SALESGR } & $-0.183 * * *$ & $-0.179 * *$ & $-0.178 * *$ & $-0.180 * * *$ & $-0.180 * *$ & $-0.385^{* * *}$ & $-0.353 * * *$ & $-0.296 * * *$ & $-0.356 * * *$ & $-0.380 * * *$ \\
\hline & {$[0.070]$} & {$[0.070]$} & {$[0.070]$} & {$[0.070]$} & {$[0.070]$} & {$[0.095]$} & {$[0.095]$} & {$[0.095]$} & {$[0.094]$} & {$[0.094]$} \\
\hline \multirow[t]{2}{*}{ MtoB } & $0.041 * * *$ & $0.041 * * *$ & $0.040 * * *$ & $0.038 * * *$ & $0.040^{* * *}$ & $0.150 * * *$ & $0.143 * * *$ & $0.126^{* * *}$ & $0.119 * * *$ & $0.128 * * *$ \\
\hline & {$[0.008]$} & {$[0.008]$} & {$[0.008]$} & {$[0.008]$} & {$[0.008]$} & {$[0.018]$} & {$[0.018]$} & {$[0.018]$} & {$[0.018]$} & {$[0.018]$} \\
\hline \multirow[t]{2}{*}{ STDDEVRET } & $4.751 * *$ & $4.632 * *$ & $4.652 * *$ & $4.031 * *$ & $4.473 * *$ & $34.265 * * *$ & $32.774 * * *$ & $31.245 * * *$ & $27.955 * * *$ & $25.322 * * *$ \\
\hline & [2.007] & [2.004] & [1.989] & [2.033] & [2.019] & [3.724] & [3.723] & {$[3.740]$} & [3.749] & {$[3.740]$} \\
\hline \multirow[t]{2}{*}{ LNSALES } & $0.211 * * *$ & $0.210 * * *$ & $0.205^{* * *} *$ & $0.199 * * *$ & $0.209 * * *$ & $0.945 * * *$ & $0.905^{* * *}$ & $0.859 * * *$ & $0.830 * * *$ & $0.905^{* * *}$ \\
\hline & {$[0.015]$} & {$[0.014]$} & {$[0.015]$} & {$[0.015]$} & {$[0.015]$} & [0.007] & {$[0.007]$} & {$[0.007]$} & {$[0.007]$} & {$[0.007]$} \\
\hline Adj. R-square & 0.398 & 0.398 & 0.4 & 0.402 & 0.398 & 0.092 & 0.093 & 0.096 & 0.096 & 0.095 \\
\hline Observations & 3787 & 3787 & 3787 & 3787 & 3787 & 3787 & 3787 & 3787 & 3787 & 3787 \\
\hline
\end{tabular}


Table 7: Effect of institutional investors on CEO pay-for-performance link in family firms

This table reports the estimates of the OLS regressions for the natural logarithm of total compensation (TOTAL_C); for the natural logarithm of cash compensation (CASH_C); and of Tobit regressions for the natural logarithm of equity compensation (EQUITY_C). All regressions include country, industry and year fixed effects. The ownership and financial variables are lagged with respect to the dependent variable. FAMILY is a dummy variable that takes the value of one when the controlling shareholder is a family. FAMILYCEO is a dummy variable that takes the value of 1 when a family member is the CEO in a family firm. TOTINST is the sum of the percentage of stakes held by institutional investors in a given company. INSTBLOCK is total percentage of shares held by institutional investors with at least $5 \%$ of the firm's capital. BOARDSIZE is the total number of executive and non-executive directors. BUSYBOARD is a dummy variable that equals one if is the board is defined as busy, which occurs when $50 \%$ or more of the board's outside directors hold three or more directorships. INDPDIR is the ratio of independent non-executive directors to board size. CEO TENURE is the time duration of CEO in this role. CEOEXPR is the total number of directorships that CEO has in other quoted companies as a proxy for CEO experience. RETURN represents annual stock return. ROA, Return on Assets, is the ratio of net income to total assets. SALESGR, sales growth is the change in sales, $M t o B$, market to book ratio, is the ratio of market value of shareholders' equity to book value of shareholders' equity. STDDEVRET is the annual standard deviation of daily stock returns. LNSALES is the natural logarithm of sales. Robust standard errors are in brackets. The symbols ***, **, * denote statistical significance at the $1 \%, 5 \%$, and $10 \%$ levels, respectively.

\begin{tabular}{|c|c|c|c|}
\hline & TOTAL_C & CASH_C & EQUITY_C \\
\hline \multirow[t]{2}{*}{ CONSTANT } & $3.125 * * *$ & $3.661 * * *$ & $-57.260 * * *$ \\
\hline & {$[0.433]$} & [0.399] & {$[0.107]$} \\
\hline \multirow[t]{2}{*}{ FAMILY } & $-0.200^{* * *}$ & $-0.256^{* * *}$ & $0.941 * * *$ \\
\hline & {$[0.067]$} & {$[0.060]$} & {$[0.106]$} \\
\hline \multirow[t]{2}{*}{ FAMILY*RETURN } & 0.123 & 0.160 & $-0.906 * * *$ \\
\hline & {$[0.163]$} & [0.147] & {$[0.213]$} \\
\hline \multirow[t]{2}{*}{ FAMILYCEO } & $-0.230 * *$ & -0.091 & $-2.213 * * *$ \\
\hline & {$[0.103]$} & [0.097] & {$[0.143]$} \\
\hline \multirow{2}{*}{ FAMILYCEO*RETURN } & -0.18 & -0.116 & $-1.440 * * *$ \\
\hline & [0.193] & {$[0.171]$} & {$[0.315]$} \\
\hline \multirow[t]{2}{*}{ TOTINST } & $0.240^{*}$ & 0.063 & $5.086^{* * *}$ \\
\hline & [0.124] & [0.112] & {$[0.271]$} \\
\hline \multirow[t]{2}{*}{ TOTINST*FAMILY } & $0.528 * *$ & $0.777 * * *$ & $-2.240 * * *$ \\
\hline & {$[0.243]$} & {$[0.216]$} & {$[0.419]$} \\
\hline \multirow{2}{*}{ TOTINST*FAMILYCEO } & 0.452 & 0.166 & $1.623^{* *}$ \\
\hline & [0.474] & [0.447] & {$[0.808]$} \\
\hline \multirow[t]{2}{*}{ TOTINST*RETURN } & $0.648^{* *}$ & $0.565^{*}$ & $3.604 * * *$ \\
\hline & {$[0.330]$} & [0.304] & {$[0.473]$} \\
\hline \multirow[t]{2}{*}{ TOTINST*FAMILY*RETURN } & -0.362 & -0.319 & 0.432 \\
\hline & {$[0.557]$} & [0.485] & [0.881] \\
\hline \multirow[t]{2}{*}{ TOTINST*FAMILYCEO*RETURN } & -0.290 & -0.399 & $7.465 * * *$ \\
\hline & {$[0.670]$} & [0.598] & [2.017] \\
\hline \multirow[t]{2}{*}{ BOARDSIZE } & $0.034 * * *$ & $0.033 * * *$ & $0.075 * * *$ \\
\hline & {$[0.006]$} & {$[0.005]$} & [0.007] \\
\hline \multirow[t]{2}{*}{ BUSYBOARD } & $0.249 * * *$ & $0.229 * * *$ & $1.965 * * *$ \\
\hline & {$[0.081]$} & {$[0.075]$} & [0.104] \\
\hline \multirow[t]{2}{*}{ INDPDIR } & $0.464 * * *$ & $0.246 * * *$ & $5.159 * * *$ \\
\hline & {$[0.098]$} & [0.089] & {$[0.187]$} \\
\hline \multirow[t]{2}{*}{ CEO TENURE } & -0.006 & $-0.006^{*}$ & $0.031 * * *$ \\
\hline & [0.003] & {$[0.003]$} & [0.008] \\
\hline \multirow[t]{2}{*}{ CEOEXPR } & $0.066 * * *$ & $0.041 * * *$ & $0.365^{* * *}$ \\
\hline & {$[0.007]$} & [0.006] & {$[0.013]$} \\
\hline
\end{tabular}




\begin{tabular}{lccc}
\hline & TOTAL_C & CASH_C & EQUITY_C \\
\hline RETURN & -0.151 & -0.146 & $-0.437^{* * *}$ \\
ROA & {$[0.103]$} & {$[0.096]$} & {$[0.148]$} \\
& $-0.074 * *$ & -0.04 & $-0.503^{* * *}$ \\
SALESGR & {$[0.037]$} & {$[0.034]$} & {$[0.068]$} \\
& $-0.168^{* *}$ & $-0.169^{* *}$ & $-0.308^{* * *}$ \\
MtoB & {$[0.078]$} & {$[0.070]$} & {$[0.097]$} \\
& $0.048^{* * *}$ & $0.040^{* * *}$ & $0.122^{* * *}$ \\
STDDEVRET & {$[0.009]$} & {$[0.008]$} & {$[0.018]$} \\
& $5.511^{* *}$ & $4.219^{* *}$ & $33.270^{* * *}$ \\
LNSALES & {$[2.199]$} & {$[1.989]$} & {$[3.745]$} \\
& $0.231^{* * *}$ & $0.203^{* * *}$ & $0.878^{* * *}$ \\
Adj R square & {$[0.016]$} & {$[0.015]$} & {$[0.007]$} \\
Observations & & & \\
\hline
\end{tabular}




\section{APPENDIX: CEO compensation, structure and Institutional ownership by country}

This table reports descriptive statistics for total wealth and components of CEO compensation by country for Western continental European firm's CEOs. The sample period is from 2001 to 2008. We identify a director as CEO from the definitions of role for executive directors. Total wealth represents the value of accumulated shareholdings (The total number of observations with available CEOs' total wealth is 2754). TOTAL_C is the total compensation. CASH_C is the total cash compensation. EQUITY_C is equity linked compensation. All is in thousands of Euros. Panel B reports descriptive statistics for the percentage of shares held by total and foreign institutional owners at Western continental European firms. The ownership is presented by country, family and non-family firms and year. The ownership data is collected from Thomson One Banker ownership module. Total Institutional Ownership (TOTINST ) and Foreign Institutional Ownership (FORINST) are the total percentage of shares held by total and foreign financial institutions. Institutional owners are banks and trusts, insurance companies, investment advisors, pension funds, research firms, sovereign wealth funds. We define an institutional investor as foreign if its country of origin is different from the country where the firm is located. The symbol *** denotes statistical significance at the $1 \%$ level for the tests between family and non-family firms.

Panel A: CEO compensation by country

\begin{tabular}{lrrrrrrrr}
\hline & & & \multicolumn{2}{c}{ TOTAL_C } & \multicolumn{2}{c}{ CASH_C } & \multicolumn{2}{c}{ EQUITY_C } \\
\hline AUSTRIA & firms & obs & Mean & Median & Mean & Median & Mean & Median \\
BELGIUM & 4 & 19 & 1344.31 & 1265.72 & 1133.29 & 991.45 & 211.02 & 95.31 \\
DENMARK & 50 & 161 & 890.71 & 550.05 & 714.99 & 528.31 & 175.72 & 0.00 \\
FINLAND & 8 & 30 & 1121.87 & 1012.99 & 860.42 & 850.55 & 261.45 & 0.00 \\
FRANCE & 13 & 51 & 2439.15 & 1170.59 & 1504.98 & 1015.68 & 934.16 & 0.00 \\
GERMANY & 253 & 1302 & 1604.20 & 640.11 & 873.24 & 550.46 & 730.96 & 0.00 \\
GREECE & 132 & 471 & 2010.68 & 1331.55 & 1565.57 & 1189.06 & 445.11 & 0.00 \\
ITALY & 5 & 13 & 706.42 & 353.07 & 706.42 & 353.07 & 0.00 & 0.00 \\
NETHERLANDS & 101 & 433 & 2434.70 & 1095.42 & 1616.48 & 872.71 & 818.22 & 0.00 \\
NORWAY & 102 & 550 & 1296.91 & 802.12 & 832.89 & 626.66 & 464.02 & 72.13 \\
PORTUGAL & 35 & 106 & 532.95 & 244.65 & 369.76 & 236.91 & 163.19 & 0.00 \\
SPAIN & 5 & 13 & 9715.58 & 1027.51 & 9660.60 & 736.57 & 54.98 & 0.00 \\
SWEDEN & 34 & 140 & 874.50 & 286.79 & 782.62 & 234.51 & 91.88 & 0.00 \\
SWITZERLAND & 119 & 613 & 667.00 & 445.21 & 629.08 & 427.19 & 37.91 & 0.00 \\
& 54 & 143 & 3133.33 & 1334.60 & 1623.91 & 1192.17 & 1509.42 & 0.00 \\
Total & & & & & & & 630.19 & 526.23 \\
\hline
\end{tabular}


Panel B: Institutional ownership by country

\begin{tabular}{|c|c|c|c|c|c|c|c|c|c|c|c|c|c|c|c|c|c|}
\hline & \multicolumn{9}{|c|}{ Total Institutional Ownership (TOTINST) } & \multicolumn{8}{|c|}{ Foreign Institutional Ownership (FORINST) } \\
\hline & $\mathbf{N}$ & 2001 & 2002 & 2003 & 2004 & 2005 & 2006 & 2007 & 2008 & 2001 & 2002 & 2003 & 2004 & 2005 & 2006 & 2007 & 2008 \\
\hline AUSTRIA & 19 & & 7.0 & 7.0 & 6.6 & 9.3 & 11.7 & 25.0 & 30.1 & & 6.2 & 6.0 & 5.7 & 8.2 & 10.4 & 23.8 & 28.8 \\
\hline BELGIUM & 161 & 15.3 & 19.1 & 20.3 & 9.4 & 11.4 & 11.4 & 15.4 & 15.6 & 5.8 & 7.8 & 7.6 & 5.6 & 5.9 & 6.7 & 10.1 & 9.8 \\
\hline DENMARK & 30 & & 8.1 & 20.0 & 18.1 & 14.0 & 15.2 & 19.8 & 17.3 & & 6.5 & 7.1 & 12.0 & 9.5 & 6.6 & 12.3 & 11.3 \\
\hline FINLAND & 51 & 15.9 & 15.2 & 14.1 & 18.7 & 18.0 & 15.9 & 25.9 & 26.5 & 9.7 & 9.4 & 8.0 & 9.1 & 8.4 & 6.1 & 18.4 & 16.7 \\
\hline FRANCE & 1302 & 22.1 & 17.0 & 17.0 & 15.8 & 16.0 & 16.6 & 19.3 & 19.5 & 7.0 & 5.6 & 5.3 & 6.0 & 5.5 & 6.1 & 9.1 & 9.1 \\
\hline GERMANY & 471 & 17.4 & 21.4 & 21.0 & 20.4 & 16.5 & 15.1 & 21.6 & 22.6 & 7.0 & 7.4 & 5.7 & 7.6 & 8.5 & 9.0 & 14.7 & 15.7 \\
\hline GREECE & 13 & 3.9 & 8.0 & 10.8 & 9.5 & 14.1 & 14.2 & 16.5 & 15.1 & 0.6 & 1.4 & 2.7 & 3.8 & 1.5 & 4.9 & 10.6 & 12.0 \\
\hline ITALY & 433 & 10.0 & 8.3 & 8.6 & 9.2 & 12.1 & 13.9 & 15.9 & 14.8 & 5.0 & 5.3 & 4.9 & 5.2 & 6.9 & 8.8 & 10.8 & 11.2 \\
\hline NETHERLANDS & 550 & 20.4 & 18.5 & 16.0 & 16.3 & 18.2 & 19.4 & 28.9 & 28.7 & 10.7 & 9.3 & 8.8 & 9.5 & 11.4 & 12.7 & 20.1 & 19.9 \\
\hline NORWAY & 106 & 23.7 & 17.6 & 13.8 & 16.6 & 16.9 & 18.7 & 19.6 & 23.1 & 9.9 & 7.7 & 7.5 & 8.6 & 6.9 & 10.1 & 10.3 & 10.8 \\
\hline PORTUGAL & 13 & & & 5.7 & 6.4 & 4.6 & 6.0 & 16.0 & 13.8 & & & 0.4 & 1.0 & 1.1 & 3.0 & 11.7 & 9.0 \\
\hline SPAIN & 140 & 11.6 & 17.6 & 14.6 & 13.7 & 12.8 & 15.5 & 18.1 & 16.5 & 4.4 & 9.2 & 7.7 & 7.1 & 5.5 & 7.0 & 8.8 & 9.2 \\
\hline SWEDEN & 613 & 21.2 & 21.1 & 22.0 & 21.9 & 25.2 & 30.3 & 30.7 & 30.0 & 6.2 & 5.5 & 5.5 & 5.0 & 6.1 & 9.2 & 9.6 & 7.0 \\
\hline SWITZERLAND & 143 & 10.3 & 11.8 & 10.9 & 13.8 & 11.5 & 14.1 & 19.0 & 18.0 & 5.1 & 8.1 & 7.8 & 10.0 & 7.3 & 9.5 & 14.8 & 13.5 \\
\hline TOTAL & 4045 & 19.4 & 17.0 & 16.8 & 16.6 & 16.7 & 17.6 & 21.4 & 21.3 & 6.9 & 6.6 & 6.2 & 6.8 & 7.1 & 8.4 & 12.2 & 12.0 \\
\hline
\end{tabular}

